\title{
GATA2 Expression by Intima-Infiltrating Macrophages Drives Early Atheroma Formation.
}

Charles Yin ${ }^{1}$, Angela M. Vrieze ${ }^{1}$, James Akingbasote ${ }^{1}$, Emily N. Pawlak ${ }^{1}$, Rajesh Abraham Jacob ${ }^{1}$, Jonathan Hu ${ }^{1}$, Neha Sharma ${ }^{1}$, Jimmy D. Dikeakos ${ }^{1}$, Lillian Barra ${ }^{1,2}$, A. Dave Nagpal ${ }^{3,4}$, Bryan Heit Bi,5 $^{\star 1,}$

\begin{abstract}
Aberrant macrophage polarization is a major contributor to the onset and progression of atherosclerosis. Despite this, macrophage polarization during in early stages of human atherosclerotic disease is poorly understood. Using transcriptomic analysis of macrophages recovered from early-stage human atherosclerotic lesions, we have identified a unique gene expression profile dissimilar to that observed in later stages of disease that is characterized by upregulation of the hematopoietic transcription factor GATA2. GATA2 overexpression in vitro recapitulated defects observed in patient macrophages, including deficiencies in the uptake and processing of apoptotic cells, and in the catalysis of atherogenic protein modifications, with GATA2 knockdown abrogating these defects. Our data describe a previously unreported macrophage differentiation state present in early atheroma formation and identifies GATA2 as a driver of macrophage functional defects during the early stages of atherosclerosis in humans.
\end{abstract}

\section{Introduction}

Macrophages are the primary immune cell type driving the onset and progression of atherosclerosis. Under homeostatic conditions macrophages are atheroprotective, through both the endocytic clearance of lipoprotein deposits in the sub-vascular space, and through efferocytosis - the phagocytic clearance of apoptotic cells. Combined, these macrophage functions prevent the accumulation of lipids and dying cells, and induce anti-inflammatory signaling, thereby countering the pathological processes required for plaque formation ${ }^{1-4}$. Although macrophages are normally capable of processing and exporting cholesterol in large amounts ${ }^{5,6}$, during atherosclerosis the burden of low-density lipoprotein (LDL) and its chemically modified variants such as oxidized LDL (oxLDL) exceed the macrophages' processing capacity, resulting in the accumulation of intracellular cholesterol and the differentiation of these macrophages into lipid-laden foam cells ${ }^{7-10}$. In response to the cellular stress associated with cholesterol accumulation, foam cells secrete pro-inflammatory cytokines, apoptose, and are cleared by neighbouring macrophages through efferocytosis ${ }^{11,12}$. In parallel, oxLDL signaling through CD36, Toll-like receptor (TLR) 2 and TLR4 on macrophages and other plaque-resident immune cells further exacerbates inflammation ${ }^{13,14}$. Critically, as atherosclerosis progresses, macrophage efferocytosis within the lesion becomes defective and apoptotic foam cells are left uncleared. These apoptotic cells eventually undergo secondary necrosis, generating a necrotic core ${ }^{15-17}$. Additionally, the release of cytokines from plaque-resident immune cells, and alarmins from necrotic cells, induces the recruitment of monocytes which first differentiate into macrophages, and subsequently into foam cells ${ }^{18,19}$. Lysosomal proteins released during necrosis further destabilize the plaque, contributing to atherosclerotic plaque rupture and exposure of thrombogenic factors contained within the plaque, resulting in thrombus formation that may lead to a stroke or myocardial infarct ${ }^{15,20,21}$.

Macrophages are phenotypically plastic cells, whose functional capabilities are determined by their polarization into specialized subtypes. These polarization states are determined by a combination of macrophage ontologeny ${ }^{22,23}$, tissue-specific cues ${ }^{24}$, host age ${ }^{25}$, and environmental cues ${ }^{26}$, which in turn drive transcriptional programs that control macrophage phenotype. These polarization states change in response to alterations in the local tissue microenvironment such as the introduction of inflammatory mediators ${ }^{26}$. Macrophage polarization is tightly entwined with the development of atherosclerosis. In mice, resident aortic macrophages are embryonically-derived, self-renewing cells characterized by the expression of scavenger receptors, MHC II and efferocytic receptors ${ }^{22}$. In mouse models two macrophage sub-types emerge within atherosclerotic lesions: haematopoietically-derived inflammatory (M1) macrophages, and a $\mathrm{TREM}^{+}$population unique to the atherosclerotic plaque that expresses a mixture of resident-macrophage markers and markers of alternatively activated (M2) cells ${ }^{27}$. While the ontology of human aortic and cardiac macrophages are not well-understood, macrophages with markers of M1-polarization (iNOS, CD86), M2-polarization (MR, dectin-1), and TREM2+-polarization (TREM2, CD9 ${ }^{\text {hi) }}$ have been identified in established plaques ${ }^{27,28}$. In advanced stages of disease, other macrophage sub-types may emerge. For example, intraplaque hemorrhage in humans gives rise to the atheroprotective Mhem macrophage sub-type, which scavenge hemoglobin and are resistant to oxidative stress ${ }^{29,30}$. While multiple macrophage polarization states have been identified in mouse models and in human atheroma samples, very little is known of the transcription factors or the tissue- and environment-specific cues which regulate their transcriptional programs. One of the best characterized atheroma-resident macrophage populations is the Mox sub-type, which in mice accounts for $30 \%$ of atheroma-resident macrophages ${ }^{31}$. Mox cells are characterized by a transcriptional profile mediated by the transcription factor Nrf2 which, when knocked out, delays atheroma formation ${ }^{32}$. Nrf2 upregulates several genes not normally expressed in M1 or M2 polarized cells, including genes for processing heme, angiogenic factors, and anti-oxidant mechanisms ${ }^{31}$.

Most investigations of macrophage gene expression in atherosclerosis have concentrated on the stages of disease following the formation of fully developed atheromas bearing a necrotic core and fibrous cap (Stage 4/5 or later in the Stary classification system ${ }^{33}$ ). As such, little is known of macrophage polarization and function during the earlier stages of plaque development. Lipid accumulation and endothelial activation at the lesion drives monocyte recruitment into the plaque and drives M1-polarization via increased recruitment of inflammatory monocytes versus non-inflammatory monocytes ${ }^{34}$. Local proliferation of these monocyte-derived macrophages then further populates the plaque with inflammatory cells ${ }^{35}$. In vitro analyses of changes in macrophage gene expression following exposure to atherogenic lipids provides some insight into the transcriptional changes that occur early in disease. Koller et al. demonstrated that exposure of RAW264.7 murine macrophages to oxidized lipids resulted in the rapid upregulation of the genes involved in the uptake of oxLDL, apoptosis and cell stress, while genes controlling cholesterol efflux and cell proliferation were downregulated ${ }^{36}$. Using human

1. Department of Microbiology and Immunology, and the Center for Human Immunology, The University of Western Ontario, London, Ontario, Canada.

2. Division of Rheumatology, Department of Medicine, The University of Western Ontario, London, Ontario, Canada.

3. Division of Cardiac Surgery, Department of Surgery, The University of Western Ontario, London, Ontario, Canada.

4. Division of Critical Care Medicine, Department of Medicine, The University of Western Ontario, London, Ontario, Canada.

5. Robarts Research Institute, London, Ontario, Canada

* Corresponding Author: (P): 519-661-3407 (E): bheit@uwo.ca

This is a preprint and has not undergone peer-review. 
bioRxiv preprint doi: https://doi.org/10.1101/715565; this version posted July 26,2019 . The copyright holder for this preprint (which was not certified by peer review) is the author/funder, who has granted bioRxiv a license to display the preprint in perpetuity. It is made available under aCC-BY-ND 4.0 International license.

monocyte-derived macrophages, Ho \& Fraiser observed a similar trend following exposure to modified LDL (moLDL), and determined that complement protein $\mathrm{C} 1 \mathrm{q}$ accelerates this response ${ }^{37}$. However, these studies were limited to hematogenous macrophages cultured in vitro, and therefore lacked the full range of ontological, tissue-specific and environmental signals which drive macrophage polarization and function in vivo.

In this study we investigated the transcriptional profile of macrophages recovered from early human aortic plaque. We identified a unique macrophage polarization state notably different from those reported from later-stage disease in both humans and mouse models. This novel differentiation state is characterized by the downregulation of several critical atheroprotective pathways including those involved in efferocytosis and cholesterol processing, and the concurrent upregulation of inflammatory/atherogenic pathways including protein citrullination. Critically, many of these pathways were found to be regulated by the aberrant expression of the transcription factor GATA2, with GATA2 overexpression in vitro recapitulating functional defects induced by oxLDL, and shRNA-mediated GATA2 knockdown abrogating these defects. Combined, our data implicate GATA2 as a key regulator of early plaque development in human atherosclerosis.

\section{Results}

\section{Macrophage Gene Expression in Early-Stage Atherosclerotic Plaque}

Human aortic punch samples were obtained from regions of the ascending aorta with minimal macroscopic atherosclerotic disease in patients undergoing coronary artery bypass graft operations. Approximately $75 \%$ of punch samples were found to contain evidence of early plaque when stained for histological markers of atherosclerosis (Figure 1A-C) and for macrophages using anti-CD163 (Figure 1D). CD163 was used in lieu of the more common marker CD68, as up to $40 \%$ of CD68 ${ }^{+}$cells in plaque are not of macrophage origin ${ }^{38}$. We observed significant levels of CD163 expression across a range of macrophage polarization states in vitro and it colocalized well with CD68 in patient plaques (Figure S1). Plaques observed in punch biopsies were characterized by the presence of lipid-laden macrophages that correlated significantly with macrophage infiltration (Figure 1D,E) and diffuse intimal thickening (Figures 1C,F,S2A-C), but lacked evidence of more advanced lesions such as the deposition of extracellular lipids in the intima (Figure 1B,E) or the accumulation of necrotic cells (Figure 1G, S2D). This pattern of macrophage influx and limited lipid accumulation is consistent with early (stage 1 or 2) atherosclerotic plaque development, as per the classification system of Stary et a ${ }^{\beta 3}$. Macrophages were selectively isolated from CD163stained tissue sections by laser capture microdissection, producing a cell population with 33-fold enrichment of the monocyte/macrophage-specific marker CD14 relative to the entire tissue section (Figure $1 \mathrm{H}$ ). For clarity, these early-atheroma macrophages will henceforth be referred to as "intima-infiltrating macrophages".
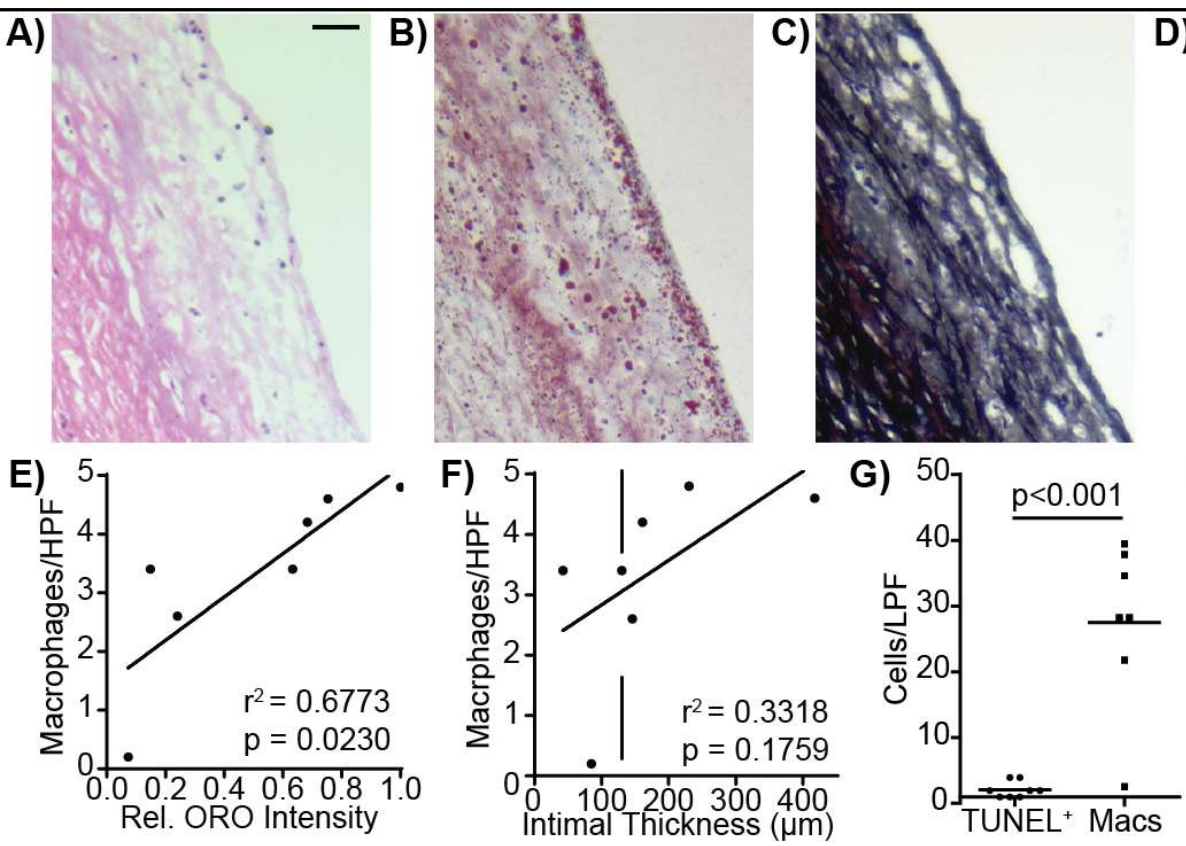
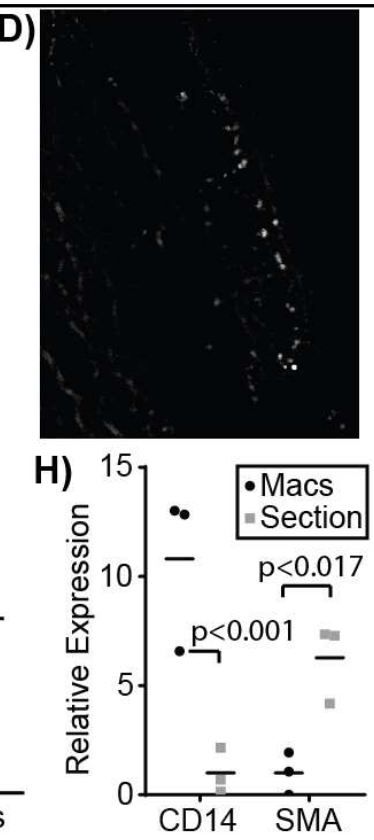

Figure 1: Identification and Recovery of Macrophages from Early Stage Plaque. Regions of plaque development were identified using serial sections from human aortic punch biopsies stained with A) H\&E, B) Oil-Red-O (ORO), C) Movats, and D) the macrophage marker CD163. E) Lipid and sterol deposition, measured by relative ORO staining, correlated strongly with macrophage numbers in high-power fields (HPF, $675 \mu \mathrm{m} \times 910 \mu \mathrm{m}$ ). F) No correlation was observed between macrophage infiltrates and intimal thickness; vertical line indicates normal aortic intimal thickness. G) Number of TUNELstained dead cells and macrophages (Macs) in low-power field images (LPF, $2510 \mu \mathrm{m} \times 1880 \mu \mathrm{m}$ ). H) Fold-enrichment in the macrophage marker CD14 and smooth-muscle marker SMA in purified CD163+ macrophages versus whole tissue sections. Fold-enrichment was calculated using GAPDHnormalized expression levels. Data is representative of (A-D) or quantifies (E-H) a minimum of 5 patients or age- and sex-matched controls. Data is plotted as individual measurements plus either a linear regression (E-F) or median $(\mathrm{G}-\mathrm{H})$. p-values were calculated using either linear regression (E-F) or with a Mann-Whitney $U$ test (G-H). Scale bars are $100 \mu \mathrm{m}$.

The gene expression profile of these intima-infiltrating macrophages was then compared to M0-differentiated, monocyte-derived macrophages from age- and sex-matched controls, identifying 3,374 differentially expressed protein-coding genes (Figure 2A-B, S3). Principal component analysis demonstrated close clustering of the gene expression profile of intima-infiltrating macrophages between patients, indicating that macrophages in early-stage atheromas develop a consistent gene expression profile (Figure 2C). Gene ontologybased clustering and gene set enrichment analysis were used to identify biological processes that are perturbed in intima-infiltrating macrophages, identifying putative defects in cholesterol homeostasis, the pathways used to engulf and degrade pathogens (phagocytosis) and apoptotic cells (efferocytosis), and antigen processing (Figure S4). As expected, given the large number of 
bioRxiv preprint doi: https://doi.org/10.1101/715565; this version posted July 26,2019 . The copyright holder for this preprint (which was not certified by peer review) is the author/funder, who has granted bioRxiv a license to display the preprint in perpetuity. It is made available under aCC-BY-ND 4.0 International license.

differentially regulated genes, multiple transcription factors were significantly up- or down-regulated (Table S1). Of these, we identified GATA2 as the only up-regulated transcription factor that has previously been implicated in coronary artery disease in humans by genetic linkage studies and is known to play an important role in myeloid cell biology. ${ }^{39-41}$ RT-PCR analysis of intima-infiltrating macrophages from five additional patients confirmed upregulation of GATA2 mRNA in intima-infiltrating macrophages (Figure 2D), and immunofluorescence staining determined that GATA2 is predominantly expressed by CD68 ${ }^{+}$cells in this tissue (Figure $2 E$ ). GATA2 expression was increased in vitro when macrophages were cultured with oxLDL (Figure S5A), and this GATA2 expression could be abrogated by inhibition of the Src-family kinase (SFK)/Syk pathway, but not the ERK1/2 pathway, downstream of the oxLDL receptor CD36 (Figure 2F) ${ }^{42}$.
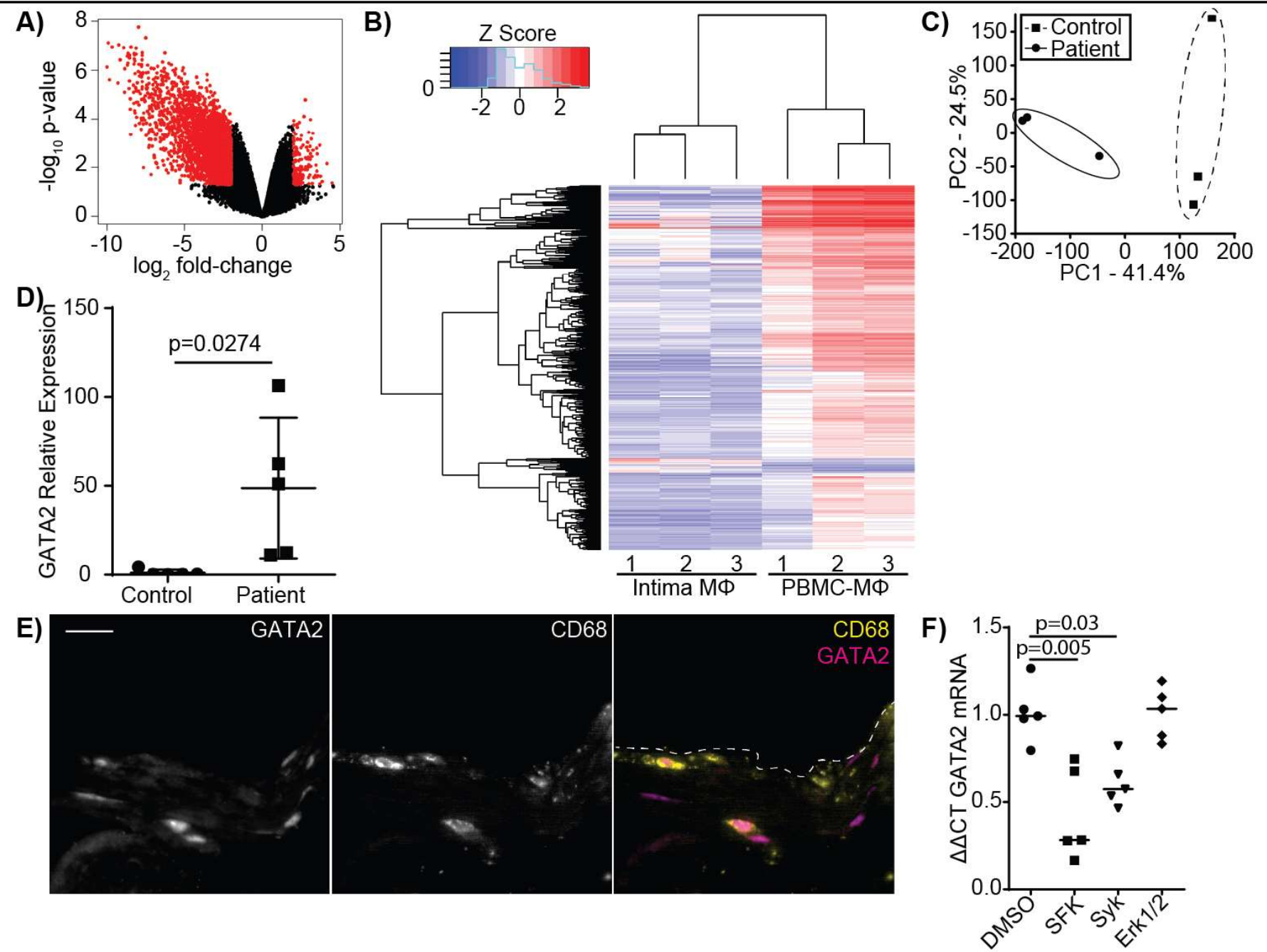

Figure 2: Microarray Analysis of Intima-Infiltrating Macrophages. A) Volcano plot illustrating the 3,374 genes up- or down-regulated more than 2-fold in intima-infiltrating macrophages compared to age- and sex-matched monocyte-derived macrophages. B) Microarray heatmap showing the gene expression profile of intima-infiltrating macrophages (Intima MФ) or age- and sex-matched monocyte-derived macrophages (PBMC-MФ). C) Principal component analysis of the gene expression profiles of intima-infiltrating macrophages (Patients) versus Control macrophages. D) RT-PCR quantification of GATA2 expression in the intima-infiltrating macrophages versus control macrophages from 5 additional subjects. GATA2 expression is normalized to GAPDH and then normalized to the mean of the controls. E) Immunofluorescence image of a representative aortic punch biopsy showing the distribution of GATA2 (magenta) and CD68 ${ }^{+}$macrophages (yellow). Scale bar is $20 \mu \mathrm{m}$. F) Normalized fold-change in GATA2 expression in THP-1 derived macrophages treated for $72 \mathrm{hrs}$ with $100 \mu \mathrm{g} / \mathrm{ml}$ oxLDL and inhibitors of Src kinases (SFK), Syk and Erk1/2. Data quantifies (A-D,F) or is representative of (E) either $3(A-C, E)$ or $5(D, F)$ independent experiments. p-values were calculated using a Mann-Whitney test (D) or ANOVA with Tukey correction (F).

\section{GATA2 Partially Regulates Macrophage Cholesterol Homeostasis}

The upregulation of GATA2 in intima-infiltrating macrophages and the dysregulation of multiple cholesterol-processing genes in the same cells suggest that GATA2 overexpression may drive defects in macrophage cholesterol homeostasis. RT-PCR analysis of intimainfiltrating macrophages confirmed that NPC1 and NPC2, which mediate the transfer of endocytosed cholesterol to cytosolic carrier proteins $^{43}$, and ABCA1, which mediates the export of cholesterol from cells ${ }^{6}$, were downregulated in intima-infiltrating macrophages (Figure $3 \mathrm{~A}-\mathrm{C}$ ). This alteration in cholesterol uptake and efflux has previously been associated with abnormal cholesterol processing and foam cell development 44,45 . To assess the functional effect of GATA2 expression on cholesterol homeostasis, THP1 macrophages were cultured with oxLDL, which induced a modest time-dependent increase in GATA2 expression (Figure S5A). Because this increase in expression was only $6 \%$ of that observed in intima-infiltrating macrophages, we used lentiviral vectors to create THP1 cells expressing GATA2 at levels similar to those observed in intima-infiltrating macrophages, as well as THP1 cells expressing a GATA2 shRNA that blocked oxLDL-induced GATA2 expression (Figure S5B-E). Using this in vitro model system, we determined that neither GATA2 
overexpression nor the GATA2 shRNA had any effect on cholesterol accumulation (Figure 3D). GATA2 expression was required enhanced cholesterol efflux in normocholesterolemic macrophages, but this effect was lost during hypercholesterolemia (Figure 3E). Combined, these results indicate that cholesterol homeostasis is perturbed in intima-infiltrating macrophages, but this loss of homeostasis is not regulated by GATA2.

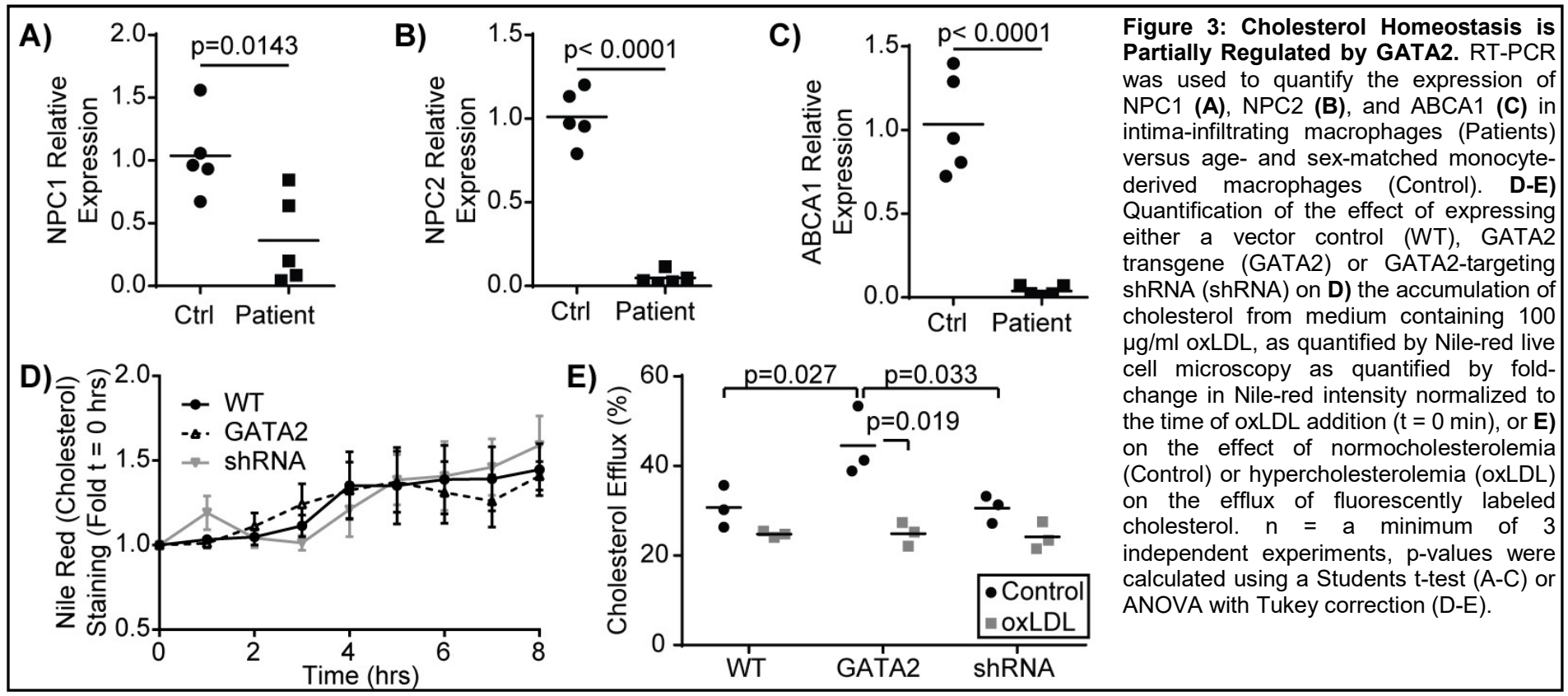

GATA2 Overexpression Impairs Phagocytosis and Efferocytosis

The efferocytic removal of apoptotic and necrotic cells is a critical atheroprotective mechanism, and failures in this process are a prerequisite for the accumulation of uncleared apoptotic cells which form the necrotic core of advanced atherosclerotic plaques ${ }^{1,2,46,47}$. Our gene expression analysis identified a reduction in the expression of genes involved in the efferocytosis of apoptotic cells and the phagocytosis of microbial pathogens (Figures S4). RT-PCR confirmed that the $\alpha_{x}$ integrin, a receptor for both complement-opsonized pathogens and CD93-opsonized $A C s^{48}$, was downregulated in intima-infiltrating macrophages (Figure 4A). Unexpectedly, integrin-linked kinase, which was downregulated in the patients analyzed in our microarray analysis (Figure S4, Table S1) was not downregulated in the patient cohort used for our RT-PCR assays (Figure 4B). In vitro, the phagocytosis of antibody-opsonized particles was profoundly impaired by both culture with oxLDL and GATA2 overexpression. Importantly, this oxLDL-induced defect was abrogated by expression of the GATA2 shRNA (Figure 4C). The same trend was observed in efferocytosis, with both the total number of apoptotic mimics engulfed per macrophage (Figure 4D) and the efficacy of apoptotic cell uptake (Figure 4E) impaired by culture with oxLDL or GATA2 overexpression, and with expression of a GATA2 shRNA restoring normal efferocytic capacity. Combined, these data indicate that GATA2 overexpression impairs the ability of macrophages to recognize and engulf both phagocytic and efferocytic targets.
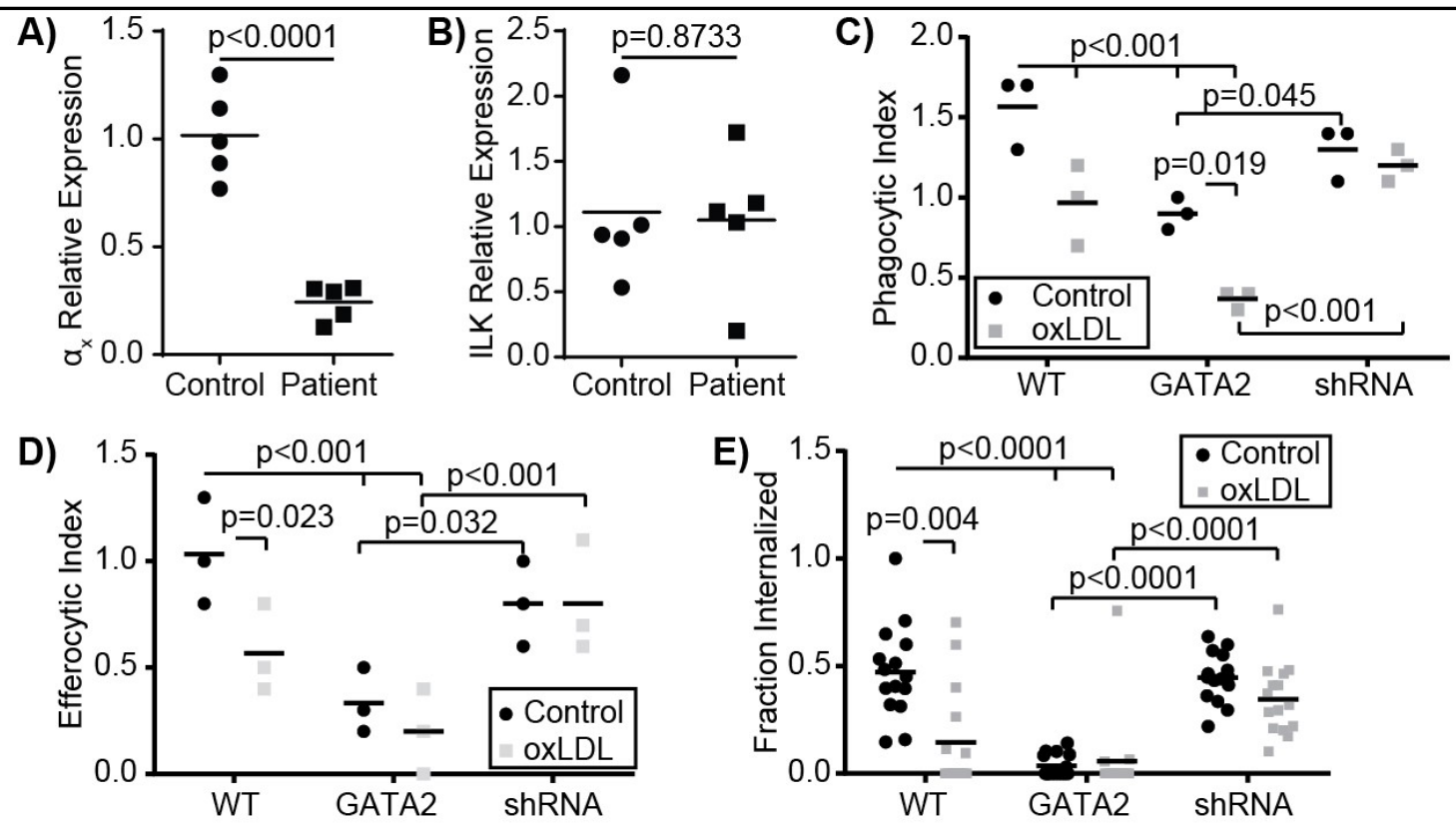

Figure 4: Phagocytosis and Efferocytosis are Impaired by GATA2 Overexpression. RT-PCR was used to quantify the expression of $\alpha_{x}$ integrin (A) and integrin-linked kinase (ILK, B) in intima-infiltrating macrophages (Patients) versus age- and sex-matched monocyte-derived macrophages (Control). C-E) Quantification of the effect of normocholesterolemia (Control) or hypercholesterolemia (oxLDL) on macrophages expressing either a vector control 

aCC-BY-ND 4.0 International license.

(WT), GATA2 transgene (GATA2) or GATA2-targeting shRNA (shRNA) on C) the phagocytic uptake of IgG-coated phagocytic mimics, D) the uptake of PtdSer-bearing apoptotic cell mimics, or E) the fraction of apoptotic Jurkat cells efferocytosed over 90 min. $n=a$ minimum of 3 independent experiments, p-values were calculated using a Students t-test (A-B) or ANOVA with Tukey correction (C-E).

\section{GATA2 Overexpression Impairs Phagosome/Efferosome Maturation}

In addition to downregulation of receptors and signaling molecules associated with the phagocytic/efferocytic uptake of particulates, intima-infiltrating macrophages also downregulated multiple genes required for the processing of microbes and apoptotic cells following uptake (Figure S4, Table S1). This included down-regulation of Rab7, which is required for phagosome/efferosome fusion with lysosomes ${ }^{49}$, multiple subunits of the vacuolar ATPase which acidifies maturing phagosomes/efferosomes ${ }^{50}$, and two subunits of the NADPH oxidase complex which produces reactive oxygen species to assist in pathogen/apoptotic cell degradation ${ }^{51}$. RT-PCR analysis confirmed the downregulation of Rab7 in intima-infiltrating macrophages (Figure 5A), and phagosome-lysosome fusion defects were observed in oxLDL-treated and GATA2-overexpressing cells, with this impairment prevented by expression of a GATA2 shRNA (Figure $5 B, C)$. In addition to lysosome fusion defects, oxLDL also induced a GATA2-dependent suppression of terminal phagosome pH (Figure $5 \mathrm{D}$ ). This was not merely a result of poor lysosome-phagosome fusion, as the acidification rate of phagosomes in the first five minutes (i.e. prior to lysosome fusion ${ }^{52}$ ) was also impaired by oxLDL in a GATA2-dependent manner (Figure 5E). Using the oxidant-sensitive dye nitro blue tetrazolium (NBT), we next determined that, as with lysosome fusion and phagosome acidification, the production of superoxide was impaired by oxLDL in a GATA2-dependent manner (Figure 5F-G). Combined, these data demonstrate that GATA2 overexpression in macrophages causes impairments in multiple processes required for the degradation of targets taken up via phagocytosis and efferocytosis.
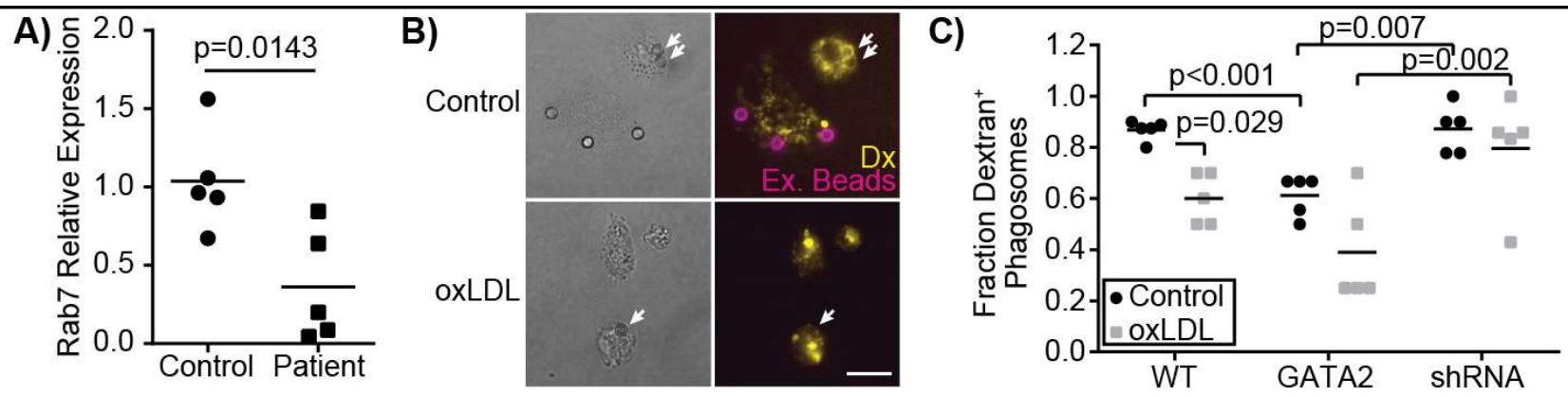

D)

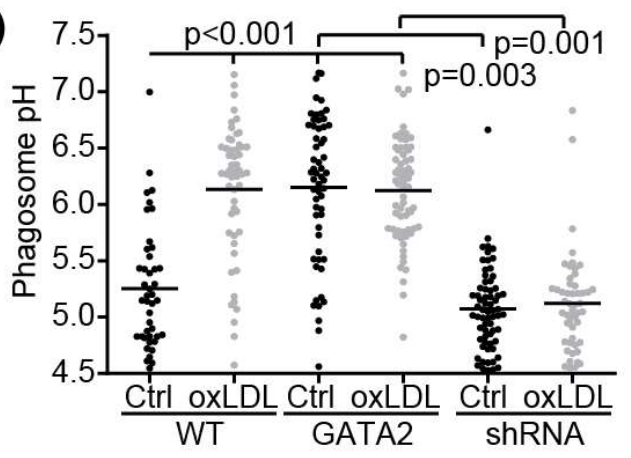

F)

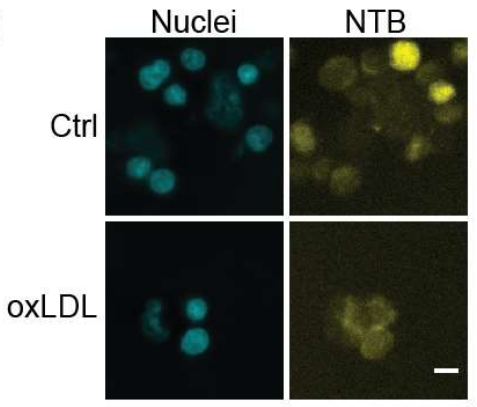

E)

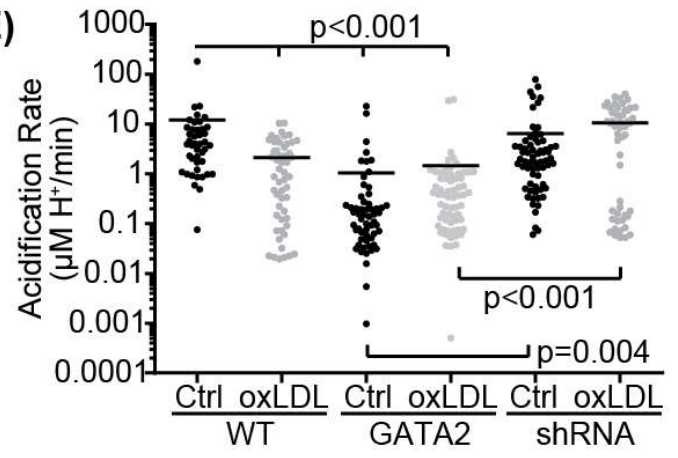

G)

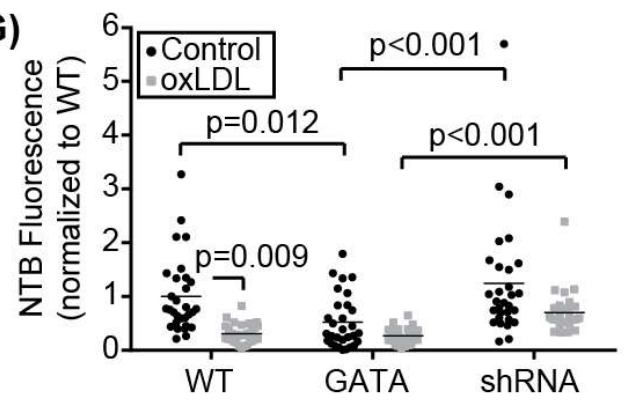

Figure 5: Phagosome/Efferosome Maturation is Impaired by GATA2 Overexpression. A) RT-PCR quantification of Rab7 expression in intima-derived macrophages (patient) versus age- and sex-matched monocyte-derived macrophage controls (Control). B-G) Quantification of the effect normocholesterolemia (Control/Ctrl) or hypercholesterolemia (oxLDL) on macrophages expressing either a vector control (WT), GATA2 transgene (GATA2) or GATA2-targeting shRNA (shRNA) on B-C) the fusion of dextran-loaded lysosomes (Yellow, Dx) with lgG-coated phagocytic targets (arrows), Non-internalized targets are stained with streptavidin-647 (Ex. Beads). Fusion is quantified 30 min after phagocytosis. D) Terminal phagosome pH and (E) phagosome acidification rate during the first 5 minutes following phagosome closure, as measured using pHrhodo ratiometric imaging. F-G) Production of superoxide $90 \mathrm{~min}$ after efferocytosing apoptotic Jurkat cells, as measured by NBT fluorescence. $p$ values were calculated using a Students t-test (A) or ANOVA with Tukey correction (C-G, E). Data is representative of $(B, F)$ or quantifies as the ensemble of individual measurements from a minimum of 3 independent experiments. Scale bars are $10 \mu \mathrm{m}(\mathrm{B})$ or $20 \mu \mathrm{m}(\mathrm{F})$. 
bioRxiv preprint doi: https://doi.org/10.1101/715565; this version posted July 26,2019 . The copyright holder for this preprint (which was not certified by peer review) is the author/funder, who has granted bioRxiv a license to display the preprint in perpetuity. It is made available under aCC-BY-ND 4.0 International license.

\section{GATA2 Overexpression Drives Citrullination}

We also observed evidence of atherogenic antigen processing in intima-infiltrating macrophages. This included perturbation of the MHC I and MHC II presentation pathways (Figure S4, Table S1), as well as upregulation of enzymes that generate atherogenic self-antigens. This included PADI3, an enzyme which deiminates arginine to form the amino acid citrulline, forming citrullinated self-antigens that contribute to intra-plaque immune complex deposition in some patients ${ }^{53-55}$. RT-PCR analysis confirmed the upregulation of PADI3 in intima-infiltrating macrophages (Figure 6A), and immunohistochemistry identified citrullinated peptides in the intima of these patients' punch samples (Figure 6B, S6A). Similar patterns of citrullination and PADI3 expression were observed in oxLDL-treated THP1 macrophages (Figures 6C,D, S6B). Using quantitative microscopy, we determined that GATA2 expression is required, but is insufficient, for oxLDL induced protein citrullination (Figure 6E). Together, these data indicate that intima-infiltrating macrophages are engaged in protein citrullination, with this activity regulated in part by GATA2.
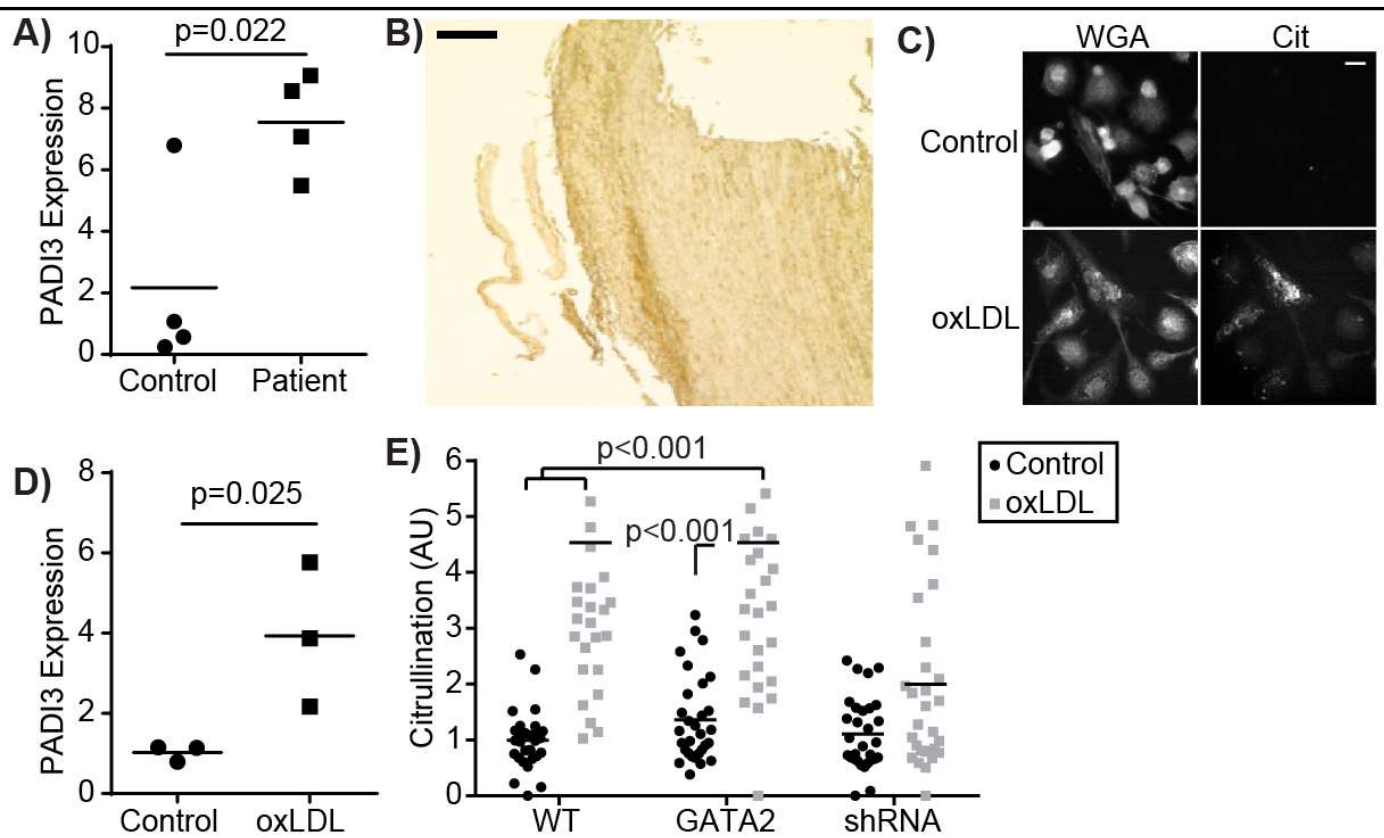

Figure 6: GATA2 Expression is Required for Plaque Citrullination. A) RT-PCR quantification of PADI3 expression in intima-derived macrophages (patient) versus age- and sex-matched monocyte-derived macrophage controls (Control). B) Low-magnification image of an aortic punch biopsies stained for citrullinated proteins. Scale bar is $1 \mathrm{~mm}$. C) THP1 derived macrophages that are either normocholesterolemca (Control) or hypercholesterolemic (oxLDL) stained with a plasma-membrane marker (WGA) and an anti-citrulline antibody (Cit). Scale bar is $10 \mu \mathrm{m}$ ). D) RT-PCR quantification of PADI3 expression in THP1-derived macrophages cultured under normocholesterolemic (Control) or hyperchoelsterolemic (oxLDL) conditions. E) Protein citrullination in THP1-derived macrophages expressing a vector control (WT), GATA2 transgene (GATA2) or GATA2-targeting shRNA (shRNA) in response to normocholesterolemic (Control) or hyperchoelsterolemic (oxLDL) conditions. Data is representative of $(A, C)$ or quantifies as the ensemble of $4(A-B)$ or 3 (C-E) independent experiments. $p$ values were calculated using a Students t-test $(A, D)$ or ANOVA with Tukey correction (E).

\section{Discussion}

In this study we have identified a previously unreported macrophage polarization state present in the early stages of human atheroma formation. This polarization state differs greatly from other previously reported atherosclerosis-associated polarization states, most of which have been identified in advanced plaque or in animal models of disease. The polarization state we have identified is consistent with macrophages transitioning from an atheroprotective to an atherogenic phenotype, with genes regulating atheroprotective processes including cholesterol homeostasis and efferocytosis downregulated in these cells, but with these cells lacking the upregulation of inflammatory genes observed in macrophages from more advanced stages of disease. This polarization state was driven, in part, by the upregulation of the transcription factor GATA2, which was responsible for the impairment of both efferocytosis and the subsequent degradation of the engulfed material. These data identify GATA2 as an important regulator of macrophage dysfunction in early human atherosclerosis and provides a detailed map of the transcriptional changes occurring in macrophages during the early stages of plaque formation.

Macrophages are phenotypically plastic cells that perform a broad range of homeostatic, immunological, and wound-healing activities. The broad functional capabilities of macrophages are created by flexible transcriptional programs driven by tissue-specific cues, inflammatory cues in the local microenvironment, age-associated transcriptional changes, and the developmental history of the macrophage ${ }^{24,56}$. These polarization states are also highly plastic and respond to changes in the local environment. For example, classically polarized M1 and M2 macrophages undergo rapid repolarization via a Nrf2-driven transcriptional program into an atherogenic polarization state upon exposure to moLDL ${ }^{31}$. In this study, we determined that macrophages isolated from early-stage human atheromas lack upregulation of classical M1 (CD80/86, iNOS) or M2 (Arg1, CD206) markers, or markers previously reported in macrophage polarization states present in late-stage plaque (TREM2, Nrf2, Atf1) ${ }^{27,30,31}$. Instead, these cells downregulated many genes involved in the processes of efferocytosis, cholesterol processing, and the degradative pathway required for proper removal of both apoptotic cells and moLDL, while upregulating immunogenic enzymes such as PADI3. This expression pattern is consistent with the events proposed to occur in early-stage plaque. Indeed, the earliest histologically definable stage of atherosclerosis is the appearance of lipid-laden macrophages within the vascular intima ${ }^{33}$ - consistent with the decreased expression of genes involved in cholesterol trafficking (NPC1/2), 
efflux (ABCA1) and intracellular cholesterol homeostasis (SOAT1, NCEH1) that we observed within intima-infiltrating macrophages. Similarly, these cells have decreased expression of many genes required for the uptake and processing of apoptotic cells, setting the stage for the accumulation of necrotic foam cells which typifies later stages of atheroma development ${ }^{47,57-59}$.

Unlike T cells, in which polarization tends to be driven by one or a small number of transcription factors, the polarization of macrophages is generally a product of multiple cooperative transcription factors ${ }^{60}$. Consistent with this, we identified 20 transcription factors which were upregulated in intima-infiltrating macrophages. Eight of these transcription factors had no known function, and five were associated with cell cycle - consistent with previous observations that lesion-resident macrophages undergo proliferation and self-renewal during atherogenesis ${ }^{61}$. This left seven transcription factors potentially driving macrophage polarization in early plaque (MSX2, GATA2, FOXD4L5, RARY, HSFX1, NKX6-1 and CIC). Of these, GATA2 was of particular interest as single nucleotide polymorphisms in this gene have previously been associated with cardiovascular disease through genome-wide association studies, although the mechanism by which these SNPs contribute to disease remains unknown ${ }^{39}$. Our data suggests that some of these SNPS may increase disease risk through inducing or enhancing the expression of GATA2 in macrophages in the vascular intima. GATA2 is a member of the GATA transcription factor family and functions as both a transcriptional activator and repressor ${ }^{62}$. GATA2 normally mediates the early stages of myelopoiesis, and must be downregulated to allow for completion of monocyte development ${ }^{40,41,63}$. GATA2 is not typically expressed by mature myeloid cells, although it is expressed in endothelial cells where it is required for the development and stability of vascular and lymphatic structures ${ }^{64-67}$. The importance of GATA2 in myelopoiesis is illustrated by patients with inactivating mutations in GATA2. A number of these patients develop MonoMAC syndrome, a primary immunodeficiency characterized by a near absence of circulating myeloid, NK and B cells, and as a result are highly susceptible to mycobacterial and Epstein-Barr Virus infections ${ }^{67,68}$. Very little is known of GATA2's role in myeloid cell activity in peripheral tissues or during immune responses, with the exception of one study demonstrating that GATA2 expression in alveolar macrophages regulates fungal phagocytosis ${ }^{69}$. Our data demonstrating that GATA2 is upregulated in response to oxLDL, that GATA2 overexpression enhances cholesterol efflux, and that GATA2 upregulation impairs efferocytosis and the processing of efferocytosed cargo, suggests that GATA2 may be upregulated in response to the cellular stress caused by cholesterol accumulation, but is ultimately maladaptive through disrupting other atheroprotective macrophage functions. While it is tempting to hypothesize that GATA2 expression may revert macrophages to an earlier developmental state, the transcriptional profile we have identified in these cells correlates poorly with the reported transcriptome of developing myeloid cells ${ }^{70}$.

We examined gene expression changes in patient macrophages by microarray using M0-polarized macrophages differentiated in vitro from peripheral blood monocytes as a control. The lack of a more comparable source of control macrophages is a significant drawback of this approach, yet a suitable source of control cells is difficult to identify. Macrophages undergo significant age-associated changes in their gene expression profile, necessitating age-matched controls ${ }^{25}$. While there is a population of macrophages in the healthy artery, these are primarily located within the adventitia, with only $2 \%$ of arterial macrophages in the intimal layer 22,71 . Moreover, these macrophages are of embryonic origin, whereas plaque-resident macrophages are predominantly hematopoietic in origin ${ }^{22,72,73}$. Thus, the use of monocyte-derived macrophages from healthy age- and sex-matched controls recapitulates the correct ontology and age but lacks the tissue-specific cues encountered in the vascular intima, and our results must be interpreted accordingly. Another drawback of our approach is that while the plaques we identified in our aortic punch samples appear to be in the early stage of development from a histological perspective, they are isolated from patients with advanced disease in the coronary circulation. Ergo, some of the observed gene expression changes may be due to systemic effects of atherosclerosis, rather than changes specific to early-stage plaque development. Nonetheless, we observed differential expression of over 3,000 protein-coding genes in intima-infiltrating macrophages compared to controls. Undoubtedly, some of this difference is due to the nature of our controls, however, many of the features that we identify as unique in the pre-atherosclerotic, lesion-resident macrophage population are consistent with our expectations of macrophage dysfunction during early stages of atherosclerotic disease, and are not obviously connected to inherent differences between tissue versus cultured macrophages ${ }^{34-37,60,74}$. These features include marked downregulation of genes involved in cholesterol homeostasis, phagocytosis/efferocytosis, phagosome/efferosome maturation, and antigen processing and presentation. Rather, we contend that these features define a novel macrophage phenotype associated with early, pre-atherosclerotic lesions.

In this study we are the first to report that GATA2 is upregulated in macrophages in early-stage human atherosclerotic plaque and is responsible for inducing both efferocytic defects and autoantigen-generating processes in these cells that contribute to the development of atherosclerosis. This GATA2-mediated dysregulation of macrophage activity is part of an aberrant polarization state which arises early in plaque development and sets the stage for disease progression. As such, targeting of GATA2 and the processes downstream of GATA2 activation may represent a novel therapeutic opportunity to limit plaque development by targeting defective efferocytosis within the atherosclerotic plaque.

Materials and Methods
Materials
pBabePuro-GATA2 (Addgene \#1285) was a gift from Gokhan
Hotamisligil75. pLXV-zsGreen lentiviral vector and pGFP-C-shLenti vector
were gifts from Dr. Jimmy Dikeakos. Coverslips, slides, Leiden chambers
and $16 \%$ paraformaldehyde (PFA) were from Electron Microscopy
Sciences (Hatfield, PA). DMEM, RPMI and fetal bovine serum (FBS) were
from Wisent (Montreal, Canada). Restriction enzymes, Gibson assembly
reagent, and ligase was from New England Biolabs (Whitby, Canada). M-
CSF, GM-CSF, INFY and IL-4 were purchased from Peprotech (Montreal,
Canada). Micro-beads were from Bangs Laboratories (Fishers, Indiana).
Lipids and cholesterol were from Avanti polar lipids (Alabaster, AL).
Lympholyte-poly and all secondary antibodies/Fab's were from Cedarlane
Labs (Burlington, Canada). pHrodo, NBT, human oxLDL, TRITC-Dextran,
nigericin, Hoechst 33342, NanoDrop 1000 Spectrophotometer, Fast
SYBR Green Master Mix, QuantStudio 5 Real-Time PCR System and the
Anti-Citrulline (Modified) Detection kit were from ThermoFisher Canada (Mississauga, ON). Human IgG, PMA, anti-modified citrulline antibody were from Sigma-Aldrich (Oakville, ON). Anti-CD163, anti-GATA2 and anti-CD68 were from Abcam (Toronto, Canada). $4.0 \mathrm{~mm}$ CleanCut RCL Aortic Punch was from QUEST Medical (Allen, Texas). Gemini Fluorescence Microplate Reader running SoftMax Pro was from Molecular Devices (San Jose, California). PureZOL RNA isolation reagent and iScript Select cDNA Synthesis Kit were from BioRad (Hercules, California). CapSure HS LCM Caps and GeneChip WT Pico Reagent Kit were from Applied Biosystems (Forest City, California) Prism 6 software was from GraphPad (La Jolla, California). FIJI was downloaded from https://fiji.sc/ ${ }^{76}$. All other materials were purchased from Bioshop Canada (Burlington, Canada). 
bioRxiv preprint doi: https://doi.org/10.1101/715565; this version posted July 26, 2019. The copyright holder for this preprint (which was not certified by peer review) is the author/funder, who has granted bioRxiv a license to display the preprint in perpetuity. It is made available under aCC-BY-ND 4.0 International license.

Human Plaque Histology \& Macrophage Isolation

Patient tissues used in this study were obtained under a discarded tissue protocol from patients undergoing elective coronary artery bypass graft surgery at London Health Sciences Centre, London, Canada. This study was reviewed and approved by the Office of Human Research Ethics at Western University Health Sciences Research Ethics Board (HSREB Reference Number: 107566) and all procedures were performed in accordance with the guidelines of the Tri-Council policy statement on human research. Since this is a discarded tissue study, we did not collect any personal health information, personal identifying information or clinical data other than the age range and the male-to-female ratio of the entire cohort. Researchers were blinded to patient identification and clinical characteristics. Aortic punch tissue specimens were obtained intraoperatively by a cardiac surgeon using a $4.0-\mathrm{mm}$ diameter aortic punch and placed in cold saline. Specimens were then bisected evenly using clean surgical scissors, with one half of the tissue used to prepare frozen sections and the other for preparing paraffin sections. For laser capture microdissection, tissue specimens were embedded in OCT freezing compound and frozen on dry ice over a period of 5-10 min within $30 \mathrm{~min}$ of collection, then placed into $-80^{\circ} \mathrm{C}$ for storage. For immunofluorescence and Oil-Red-O (ORO) staining, tissue specimens were fixed in fresh $4 \%$ paraformaldehyde (PFA) for $24 \mathrm{hr}$ at $4{ }^{\circ} \mathrm{C}$, placed in PBS $+15 \%$ sucrose until the tissue lost buoyancy ( $4 \mathrm{hr})$, and then placed into PBS $+30 \%$ sucrose overnight at $4{ }^{\circ} \mathrm{C}$. For all other stains, paraffin-embedded sections were fixed $4 \%$ PFA for $24 \mathrm{hr}$ at $4{ }^{\circ} \mathrm{C}$, then stored in $70 \%$ ethanol. Specimens were dehydrated by $1 \mathrm{hr}$ immersion in $70 \%$ and $95 \%$ ethanol, followed by four immersions in 100\% ethanol (1, 1.5, 1.5 and $2 \mathrm{hrs}$ ). Sections were cleared with two $1 \mathrm{hr}$ immersions in xylene, then immersed two times $1 \mathrm{hr}$ in paraffin wax $\left(58^{\circ} \mathrm{C}\right)$. Processed tissues were embedded into paraffin blocks.

OCT-embedded tissues were sectioned into $10 \mu \mathrm{m}$ sections and paraffinembedded samples at $5 \mu \mathrm{m}$, and placed onto clean, RNAse-free slides. All histology (H\&E, ORO, Movat's pentachrome stain and TUNEL stain) was performed at the Robarts Molecular Pathology core.

For laser capture microdissection (LCM), slides were stored at -80C until processing. Slides were fixed in ice-cold acetone for $2 \mathrm{~min}$, air-dried for 30 $\mathrm{sec}$ and stained with primary antibody (anti-CD163, 30-60 $\mu \mathrm{g} / \mathrm{mL}, 3 \mathrm{~min}$ ), washed $2 x$ with PBS, and stained with a secondary antibody $(1: 100$ dilution, $3 \mathrm{~min}$ ). CD163 was used in lieu of CD68, as CD163 is found on all human macrophages where as CD68 stains cells in the atheroma of both macrophage and smooth muscle origin ${ }^{38}$. After two PBS washes, the slides were dehydrated by sequential addition of $75 \%, 95 \%$ and $100 \%$ ethanol ( $30 \mathrm{sec} / \mathrm{step}$ ) and dried by immersion in xylene for $5 \mathrm{~min}$. LCM was performed on an ArcturusXT Laser Capture Microdissection System (Applied Biosystems) using CapSure HS LCM Caps. Samples were captured using IR capture laser of $15 \mu \mathrm{m}$ diameter at $70 \mathrm{~mW}, 1,500 \mu \mathrm{sec}$ and 1 hit per capture. A minimum of 200 captures per section across four consecutive sections was performed to obtain sufficient cell numbers for downstream analysis.

\section{Microscopy \& Image Analysis}

Unless otherwise noted, all microscopy was performed using a Leica DMI6000B microscope equipped with 40×/1.40NA, 63×/1.40NA and $100 \times / 1.40 \mathrm{NA}$ objectives, photometrics Evolve-512 delta EM-CCD camera, heated $/ \mathrm{CO}_{2}$ perfused stage, Chroma Sedat Quad filter set with blue (Ex: 380/30, Em: 455/50), green (Ex: 490/20, Em: 525/36), red (Ex: 555/25, Em: 605/52) and far-red (Ex: 645/30, Em: 705/72) filter pairs, and the LAS-X software platform. All image analysis was performed in $\mathrm{FIJI}^{76}$. For quantitative imaging, the same exposure intensity, exposure time and EM-CCD gain setters were used within a single experiment, and controlnormalized data used for comparisons between experiments.

\section{Primary Macrophage Culture}

The collection of blood from healthy donors was approved by the Health Science Research Ethics Board of the University of Western Ontario and was performed in accordance with the guidelines of the Tri-Council policy statement on human research. Blood was drawn from age- and sexmatched volunteers without diagnosed coronary artery disease by venipuncture. Blood was collected with heparinized tubes, $5 \mathrm{ml}$ of blood layered over $5 \mathrm{ml}$ of Lympholyte-poly, and centrifuged at $300 \times \mathrm{g}$ for $35 \mathrm{~min}$. The top band of cells was collected, washed once $(300 \times \mathrm{g}, 6 \mathrm{~min}$, $20^{\circ} \mathrm{C}$ ) with phosphate buffered saline (PBS, $137 \mathrm{mM} \mathrm{NaCl}, 10 \mathrm{mM}$ $\mathrm{Na}_{2} \mathrm{HPO}_{4}$ ), and resuspended at $2 \times 10^{6}$ cells/ml in RPMI-1640 + 10\% FBS $+1 \%$ antibiotic-antimycotic. $200 \mu$ l of this suspension was placed on sterile glass coverslips for $1 \mathrm{~h}$ at $37^{\circ} \mathrm{C}$, washed twice with PBS, and then differentiated into M0-polarized macrophages as per our published protocols $^{52,77}$

\section{Microarray}

Total RNA was prepared from patient aortic punch macrophages or $\mathrm{MO}$ polarized control macrophages by TRIzol extraction. RNA quality was checked using a 2100 Bioanalyzer Instrument (Agilent, Santa Clara, California), with samples below an A260/280 of 1.5 and/or RIN of 7 rejected from analysis. A minimum of $2.0 \mu \mathrm{g}$ of total RNA was from each sample was used in the microarray. RNA samples were prepared for array hybridization using the GeneChip WT Pico Reagent Kit according to the manufacturer's instructions with 12 cycles of pre-in vitro transcription amplification. Poly-A RNA standards provided by the manufacturer were used as exogenous positive controls. Samples were analyzed on the GeneChip Human Gene 2.0 ST Array chip hybridized on the GeneChip Scanner $30007 G$ System (Applied Biosystems) according to the manufacturer's recommended instructions. Raw microarray data were analyzed using the Partek Genomics Suite platform (Partek), with reads normalized by a Robust Multi-array Average (RMA) procedure with quantile normalization. Mixed-model ANOVA was used to identify differentially expressed genes with a foldchange cutoff of 2.0 and $p$-value cutoff of $p<0.05$. Unsupervised hierarchical clustering of all differentially expressed genes was performed to generate a heat map of differential gene expression. Results were verified using Bioconductor ${ }^{78}$. The oligo package was used to read in raw microarray data files and perform RMA normalization, and the limma package used to identify differentially expressed genes using a linear model approach along with an empirical Bayes method to better estimate errors in log-fold change.

Partek Genomics Suite was used to perform gene ontology microarray data using GO ANOVA, with analysis restricted to groups with more than two and fewer than 150 genes. The top $100 \mathrm{GO}$ biological function terms were visualized using the REVIGO online software platform (Rudjer Boskovic Institute, Zagreb, Croatia). Gene set enrichment analysis (GSEA) was performed using the Gene Set Enrichment Analysis software platform (Broad Institute, Cambridge, Massachusetts) with publiclyavailable annotated gene sets (cholesterol homeostasis, antigen_processing_presentation, fcr_mediated_phagocytosis, phagosome maturation) obtained from the Molecular Signatures Database (M $\bar{M}$ SigDB). Analysis was run using 10,000 permutations with FDR $<0.25$.

\section{THP-1 Cell Culture}

THP-1 human monocytes were cultured in DMEM $+10 \%$ FBS, and split upon reaching a density of $\sim 2 \times 10^{6} / \mathrm{ml}$. To generate THP-1 derived macrophages, \#1.5 thickness, $18 \mathrm{~mm}$ diameter circular coverslips were placed into the wells of a 12 -well plate, $1 \times 10^{5}$ THP- 1 cells placed into each well cultured for $72 \mathrm{hrs}$ in DMEM $+10 \%$ FBS + 100 nM PMA. Cells were then incubated with human oxLDL at a concentration of $100 \mu \mathrm{g} / \mathrm{mL}$ for 72 hrs (THP-1 cells ${ }^{79}$ ). oxLDL-treated cells were washed with PBS to remove excess oxLDL and were placed into fresh, oxLDL-free media prior to use.

\section{Cloning}

GATA2 was sub-cloned from pBabePuro-GATA2 into the pLXV-zsGreen lentiviral vector by restriction cloning, using EcoRI as per the manufacturer's instructions. GATA2 shRNA was ordered as an oligo (5'AAGGA TCCAG CAAGG CTCGT TCCTG TTCAT CAAGA GTGAA CAGGA ACGAG CCTTG CTTTT TTACC GGTAA-3') and cloned into into pGFP-C-shLenti by restriction cloning with BamHI and Agel. These were packaged into a VSV-G pseudotyped lentiviral vector using HEK 293T cells expressing pMD2.G (2 ng, Addgene \#12259), pCMV-DR8.2 (5 ng, Addgene \#12263) and $2.5 \mu \mathrm{g}$ of the lentiviral vector. $72 \mathrm{hrs}$ post transfection, virus was purified and stored as described previously $-80^{\circ} \mathrm{C}$ ${ }^{80}$. THP-1 cells were transduced by adding $500 \mu \mathrm{L}$ of viral isolate to $1 \times 10^{6}$ of THP-1 cells with $8 \mu \mathrm{g} / \mathrm{mL}$ polybrene. One week later, transduced cells were fluorescence-activated cell-sorted based on their expression of the zsGreen/GFP marker encoded by the vectors. All primer and shRNA sequences can be found in Supplemental Table 2.

\section{Immunoblotting}

At least $5 \times 10^{5}$ cells were lysed in Laemmli's buffer $+10 \% \beta$ mercaptoethanol and Halt protease inhibitor cocktail, boiled briefly, separated on a $10 \%$ SDS-PAGE gel, and transferred to nitrocellulose membrane. The membrane was blocked for at least one hour with Trisbuffered saline with $0.1 \%$ Tween 20 (TBS-T) $+5 \%$ bovine serum albumin in PBS, incubated for $1 \mathrm{hr}$ with anti-GATA2 antibody (1:500 dilution) or anti-GAPDH (1:1000) in TBS-T $+2.5 \%$ milk powder. The blot was washed 
bioRxiv preprint doi: https://doi.org/10.1101/715565; this version posted July 26, 2019. The copyright holder for this preprint (which was not certified by peer review) is the author/funder, who has granted bioRxiv a license to display the preprint in perpetuity. It is made available under aCC-BY-ND 4.0 International license.

$3 \times 15 \mathrm{~min}$ in TBS-T, and then a 1:10,000 dilution of an appropriate IR700 or IR800 secondary antibody added for $30 \mathrm{~min}$ to $1 \mathrm{hr}$ in TBS-T $+5 \%$ bovine serum albumin in PBS. The blots were washed $3 \times 15$ min washes in TBS-T and imaged using an Odyssey CLx (LI-COR Biosciences, Lincoln, Nebraska).

\section{Real-Time PCR}

Total RNA was isolated from cells or patient tissues through acid guanidinium thiocyanate-phenol-chloroform extraction using PureZOL RNA isolation reagent. Cells or tissues were suspended in PureZOL, vortexed briefly, and incubated for $5 \mathrm{~min}$ at room temperature. Chloroform was added $1: 5 \mathrm{v} / \mathrm{v}$ and incubated for another $5 \mathrm{~min}$ with intermittent agitation. Samples were centrifuged for $15 \mathrm{~min}$ at $12,000 \times \mathrm{g}$ and $4{ }^{\circ} \mathrm{C}$, then the aqueous layer transferred to a fresh tube to which an equal volume of isopropanol and $0.5 \mu \mathrm{L}$ of $20 \mathrm{mg} / \mathrm{mL}$ glycogen were added. Samples were incubated at $-80^{\circ} \mathrm{C}$ for at least $30 \mathrm{~min}$, centrifuged for $15 \mathrm{~min}$ at $12,000 \times \mathrm{g}$ and $4{ }^{\circ} \mathrm{C}$, and the RNA pellet washed $2 \times$ with $75 \%$ ethanol, air dried for approximately $5 \mathrm{~min}$ at room temperature and reconstituted in a minimal amount of RNase-free $d_{d H_{2}} \mathrm{O}$. RNA concentration and quality were measured using a NanoDrop 1000 Spectrophotometer. cDNA was generated using the iScript Select cDNA Synthesis Kit according to the manufacturer's instructions, with an equal amount of starting RNA an equal mix of random and oligo(dT)20 primers. cDNA concentration and quality were checked using a spectrophotometer prior to use in qPCR reactions. qPCR was performed using the Fast SYBR Green Master Mix and an equal amount of starting CDNA. PCR reactions were run on a QuantStudio 5 Real-Time PCR System for 40 cycles. Relative transcript express was calculated using the $\Delta \Delta \mathrm{Ct}$ method with $18 \mathrm{~S}$ used as the housekeeping gene. All RT-PCR primer sequences can be found in Supplemental Table 2.

\section{Phagocytosis and Efferocytosis Assays}

Phagocytosis and efferocytosis assays were performed as described previously ${ }^{77,81}$. Briefly, phagocytic targets were generated by washing 10 $\mu \mathrm{l}$ of $5 \mu \mathrm{m}$ diameter $\mathrm{P}(\mathrm{S} / \mathrm{DVB})$ polystyrene beads $(6,000 \times \mathrm{g} / 1 \mathrm{~min})$ with 1 $\mathrm{ml}$ of PBS. Beads were suspended in $100 \mu \mathrm{l}$ of PBS $+0.1 \mathrm{mg} / \mathrm{ml}$ human IgG and incubated at $20^{\circ} \mathrm{C}$ for $30 \mathrm{~min}$. Beads were then washed as above and suspended in $1 \mathrm{ml}$ of DMEM. Efferocytic targets were prepared by suspending a $4 \mu \mathrm{mol}$ mixture of $20 \%$ phosphatidylserine, $79.9 \%$ phosphatidylcholine and $0.1 \%$ biotin-phosphatidylethanolamine in chloroform, and to this adding $10 \mu \mathrm{l}$ of $3 \mu \mathrm{m}$ diameter silica beads. After a 1 min vortex, the chloroform was evaporated with nitrogen and the beads suspended in $1 \mathrm{ml}$ of PBS. The beads were then washed $3 \times$ as described above, and then suspended in $1 \mathrm{ml}$ of DMEM. These beads were then added to macrophages at a 10:1 bead:macrophage ratio, spun at $200 \times \mathrm{g}$ for $1 \mathrm{~min}$ to force contact between the cells and beads, and then incubated for the indicated time. The samples were then fixed with 4\% PFA for 20 min, washed, and if required, non-internalized beads detected by incubation for $20 \mathrm{~min}$ in PBS $+1: 1000$ dilution of anti-human Cy3secondary antibody, or DMEM $+1: 500$ dilution of Alexa-555 labeled streptavidin. Samples were then washed $3 x$ in PBS or DMEM and mounted on slides with Permafluor and imaged.

\section{Lysosome Fusion}

Lysosomes in THP-1 derived macrophages were loaded with $100 \mu \mathrm{g} / \mathrm{mL}$ $10,000 \mathrm{MW}$ TRITC-conjugated dextran for $16 \mathrm{hrs}$, followed by a $90 \mathrm{~min}$ chase with serum-free RPMI. IgG-coated beads, prepared as above, were added at a 10:1 bead:macrophage ratio and briefly centrifuged for $1 \mathrm{~min}$ at $400 \times \mathrm{g}$, then incubated for $30 \mathrm{~min}$ at $37{ }^{\circ} \mathrm{C}$ and $5 \% \mathrm{CO}_{2}$. Following incubation, cells were washed $1 \times$ with PBS and labelled 1:1,000 with a Cy5-conjugated anti-human IgG secondary antibody to label noninternalized beads. Cells were washed $3 \times 5$ min with PBS, fixed with $4 \%$ PFA for $20 \mathrm{~min}$, washed an additional $3 \times 5 \mathrm{~min}$ and mounted onto glass slides using Permafluor. Samples were imaged at $63 \times$ magnification, using the red (dextran) and far-red (beads) channels.

\section{Phagosome $\mathrm{pH}$}

Human IgG was labeled with pHrodo as per the manufacturer's instructions, and phagocytic targets prepared as described above using a 500:1 ratio of pHrodo-lgG:Alexa-647-labeled irrelevant antibody. Live cell microscopy was performed at $63 \times$ magnification, using point-visiting to image 4-5 locations (20-30 cells) per condition. The media was then replaced with DMEM + phagocytic targets and a 90 min timelapse captured at $2 \mathrm{~min} /$ frame using the DIC, red (pHrodo) and far-red filter sets, maintaining the same camera and exposure settings used across all experimental conditions within an individual experiment. At the end of the experiment the media was replaced with high-potassium media $+10 \mu \mathrm{g} / \mathrm{ml}$ nigericin at a pH pf 4.0, 5.0,6.0 and 7.0. The cells were imaged after each media change, thereby providing an in situ $\mathrm{pH}$ calibration for each phagosome. The resulting images were imported into FIJI, individual beads tracked using the manual tracking plugin and the pHrodo:Alexa-647 ratio measured in each phagosome at each time point and the $\mathrm{pH}$ determined using the data from the calibration images. Phagosomal FITC staining was normalized to the integrated FITC intensity across the whole cell at the first time point.

\section{Oxidant Production}

A fluorescence microscopy-based NBT assay protocol was used to assess macrophage NADPH oxidase activity ${ }^{82}$. Apoptotic Jurkat cells were generated as per our published protocls ${ }^{77,81}$ and added to PMAdifferentiated THP-1 cells at a 10:1 Jurkat:macrophage ratio. Samples were centrifuged for $1 \mathrm{~min}$ at $400 \times \mathrm{g}$ to force contact between the macrophages and ACs, and NBT was added to the medium to a final concentration of $100 \mu \mathrm{g} / \mathrm{mL}$. After $1 \mathrm{hr}$ incubation at $37{ }^{\circ} \mathrm{C}$ and $5 \% \mathrm{CO}_{2}$ cells were washed $3 \times 5 \mathrm{~min}$ and fixed with $4 \%$ PFA for $20 \mathrm{~min}$. Cells were washed $3 \times 5$ min with PBS and mounted onto slides using Permafluor. Fluorescence of diformazan deposits formed were imaged on using at $63 \times$, using the far-red fluorescence channel.

\section{Cholesterol Uptake}

Cholesterol accumulation was measured by staining with either ORO or Nile Red (NR). ORO solution (1:250 w/v ORO powder in isopropanol) was diluted $3: 2$ in $\mathrm{ddH}_{2} \mathrm{O}$ and passed through a $0.2 \mu \mathrm{m}$ filter. Cells were washed $1 \times$ with PBS, fixed with $4 \%$ PFA for $20 \mathrm{~min}$, washed an additional $3 \times$, washed briefly with $3: 2 \mathrm{v} / \mathrm{v}$ mixture of isopropanol and $\mathrm{dd}_{2} \mathrm{O}$, and allowed to dry. Cells were then covered with the minimum volume of ORO working solution and allowed incubated for $5 \mathrm{~min}$, washed $3 \times 5$ min with PBS prior to mounting for imaging. ORO accumulation was quantified by extracting stained cells with $100 \%$ isopropanol for $10 \mathrm{~min}$ at room temperature with gentle agitation, and absorbance measured at $518 \mathrm{~nm}$. $\mathrm{NR}(1 \mathrm{mg} / \mathrm{ml}$ in acetone) was diluted 1:100 into PBS or serum-free DMEM. For fixed cell staining, the PBS solution was added to fixed and washed cells for $5 \mathrm{~min}$, followed by $3 \times 5 \mathrm{~min}$ with PBS. For live-cell staining, the DMEM solution was added to cells in a Leiden chamber, and images acquired every $15 \mathrm{~min}$ for $8 \mathrm{hrs}$ at $63 \times$ magnification, using the red fluorescence channel.

\section{Cholesterol Efflux}

Cholesterol efflux was measured as described by Sankaranarayanan et $a^{\beta 3}$. Briefly, BODIPY-cholesterol and unlabeled cholesterol $(1: 5 \mathrm{v} / \mathrm{v})$ were mixed and dried under nitrogen, solubilized in MEM-HEPES (MEM media with $10 \mathrm{mM}$ HEPES, pH 7.4) $+20 \mathrm{mM}$ methyl- $\beta$-cyclodextran (MBCD)) at a molar ratio of $1: 40$ cholesterol:MBCD. The mixture sonicated at $37^{\circ} \mathrm{C}$ for $30 \mathrm{~min}$, placed onto a stirring hot plate pre-at $37^{\circ} \mathrm{C}$ for $3 \mathrm{hrs}$. Immediately prior to use this labeling media is sonicated at $37^{\circ} \mathrm{C}$ for $30 \mathrm{~min}$ and filtered through a $0.45 \mu \mathrm{m}$ filter. Apolipoprotein $\mathrm{B}(\mathrm{ApoB})$-depleted human serum was prepared by adding $1: 40 \mathrm{v} / \mathrm{v} 1 \mathrm{M} \mathrm{CaCl}{ }_{2}$ to whole human plasma, incubated for $1 \mathrm{hr}$, and serum separated by centrifugation for $5 \mathrm{~min}$ at $1,000 \times \mathrm{g}$. ApoB was then precipitated by addition of $20 \%$ PEG 8,000 in $200 \mathrm{mM}$ glycine buffer, $\mathrm{pH} \mathrm{7.4,} \mathrm{at} \mathrm{a} \mathrm{2:5} \mathrm{v/v} \mathrm{ratio.} \mathrm{The} \mathrm{mixture} \mathrm{is} \mathrm{allowed} \mathrm{to}$ incubate for $20 \mathrm{~min}$ and then centrifuged for $30 \mathrm{~min}$ at $10,000 \times \mathrm{g}$ and $4{ }^{\circ} \mathrm{C}$.

THP-1 cells were cultured in a 48-well plate to a density of 75,000 cells/well and differentiated into macrophages by culture with $100 \mathrm{nM}$ PMA for 24 hrs prior. Cells were washed $1 \times$ with PBS and incubated with 250 $\mu \mathrm{L} /$ well of labelling media for $1 \mathrm{hr}$, washed $2 \times$ with MEM-HEPES, and then incubated with serum-free RPMI $+0.2 \%$ BSA for 16 hrs. Cells were washed $2 \times$ with MEM-HEPES, then incubated with MEM-HEPES $+10 \%$ apoB-depleted serum for $4 \mathrm{hrs}$. All procedures were performed at $37^{\circ} \mathrm{C}$ and $5 \% \mathrm{CO}_{2}$. Media from each well was collected, filtered through a 0.45 $\mu \mathrm{m}$ filter and fluorescence intensity (ex. $482 \mathrm{~nm}$, em. $515 \mathrm{~nm}$ ) was recorded using a Gemini Fluorescence Microplate Reader (Molecular Devices). Negative controls were solubilized with $4 \%$ cholic acid for $4 \mathrm{hrs}$, the supernatants filtered through a $0.45 \mu \mathrm{m}$ filter, and fluorescence intensity was recorded and used as the baseline value for total cholesterol present within the cells. The percent cholesterol efflux was calculated as fluorescence intensity of media divided by fluorescence intensity of cholic acid.

\section{Citrullination}

Cells or tissues sections were incubated with wheat germ agglutinin (1:200 in PBS), 10 min at room temperature, then washed three times in PBS and permeabilized for $10 \mathrm{~min}$ with a $0.2 \%$ Triton $\mathrm{X}-100$ solution at room temperature. Cells were then washed three times in PBS, incubated with equal volumes of modification reagent $\mathrm{A}(0.5 \% \mathrm{FeCl} 2,4.6 \mathrm{M}$ sulfuric acid, 
bioRxiv preprint doi: https://doi.org/10.1101/715565; this version posted July 26, 2019. The copyright holder for this preprint (which was not certified by peer review) is the author/funder, who has granted bioRxiv a license to display the preprint in perpetuity. It is made available under aCC-BY-ND 4.0 International license.

and $3.0 \mathrm{M}$ phosphoric acid) and modification reagent $\mathrm{B}(0.5 \% 2,3-$ butanedione monoxime, $0.25 \%$ antipyrine, $0.5 \mathrm{M}$ acetic acid) at $37^{\circ} \mathrm{C}$ for 3 h. Cells were then washed three times in PBS, blocked for $1 \mathrm{hr}$ with $5 \%$ FBS, then incubated for $1 \mathrm{~h}$ with anti-modified citrulline or an isotype control at $1 \mu \mathrm{g} / \mathrm{ml}$ in 5\% FBS. Cells were washed three times in PBS and incubated with a 1:1000 dilution of Cy3-labeled anti-human secondary antibody in $5 \%$ FBS for $1 \mathrm{hr}$. Cells were washed three times with PBS, counter-stained with $2 \mu \mathrm{g} / \mathrm{ml}$ Hoechst for $10 \mathrm{~min}$, washed a final three times and mounted on coverslips with Permafluor mounting medium.
Statistics and Data Analysis

All datasets were tested for normal distribution using a Shapiro-Wilk test. Normally distributed data is presented as mean \pm SEM and analyzed using a Students $T$-test or ANOVA with Tukey correction. Non-parametric data is presented as median \pm interquartile range and analyzed using a KruskalWallis test with Dunn correction. All statistical analyses were performed using Graphpad Prism 6.

\section{Acknowledgements}

The authors would like to thank Dr. Edward J. Tweedie (Department of Pathology and Laboratory Medicine, The University of Western Ontario, London, Ontario, Canada) for his assistance with the histological classification of the aortic biopsy samples. David Carter (London Regional Genomics Centre, Robarts Research Institute, London, Ontario, Canada) for his assistance with the microarray experiments and data analysis, Caroline O'Neil (Molecular Pathology Core Facility, Robarts Research Institute) for her help with tissue histology and laser capture microdissection, and Dr. Kristin Chadwick (London Regional Flow Cytometry Facility, Robarts Research Institute) for her assistance with FACS-based cell sorting. This study was funded by a Canadian Institutes of Health Research (CIHR) Operating Grant MOP-123419, an Ontario Ministry of Research and Innovation Early Research Award, and a University of Western Ontario Accelerator grant to $\mathrm{BH}$. CY was funded by a Vanier PhD Scholarship and CIHR Md/PhD studentship. JDD was funded by a Canadian Institutes of Health Research Operating Grant MOP-389413. ENP was funded by an Alexander Graham Bell Doctoral Canada Graduate Scholarship from the Natural Sciences and Engineering Council. JA was funded by the Bone and Joint Institute at the University of Western Ontario. The funding agencies had no role in study design, data collection and analysis, decision to publish, or preparation of the manuscript.

\section{Conflict of Interest}

The authors declare no financial or commercial conflict of interest.

\section{References}

1. Thorp E, Cui D, Schrijvers DM, Kuriakose G, Tabas I. Mertk receptor mutation reduces efferocytosis efficiency and promotes apoptotic cell accumulation and plaque necrosis in atherosclerotic lesions of apoe-/- mice. Arterioscler Thromb Vasc Biol. 2008;28:1421-8.

2. Foks AC, Engelbertsen D, Kuperwaser F, Alberts-Grill N, Gonen A, Witztum JL, Lederer J, Jarolim P, DeKruyff RH, Freeman GJ, Lichtman AH. Blockade of Tim-1 and Tim-4 Enhances Atherosclerosis in Low-Density Lipoprotein Receptor-Deficient Mice. Arterioscler Thromb Vasc Biol. 2016;1-10.

3. Wan E, Yeap X-YY, Dehn S, Terry RL, Novak ML, Zhang S, Iwata S, Han X, Homma S, Drosatos K, Lomasney JW, Engman DM, Miller SD, Vaughan DE, Morrow JP, Kishore R, Thorp EB. Enhanced Efferocytosis of Apoptotic Cardiomyocytes Through MER Tyrosine Kinase Links Acute Inflammation Resolution to Cardiac Repair After Infarction. Circ Res. 2013;113:1004-12.

4. Elliott MR, Koster KM, Murphy PS. Efferocytosis Signaling in the Regulation of Macrophage Inflammatory Responses. J Immunol. 2017;198:1387-1394.

5. Werb Z, Cohn ZA. Cholesterol metabolism in the macrophage. I. The regulation of cholesterol exchange. J Exp Med. 1971;134:1545-69.

6. Chistiakov DA, Bobryshev Y V, Orekhov AN. Macrophagemediated cholesterol handling in atherosclerosis. J Cell Mol Med. 2016;20:17-28.

7. Kellner-Weibel G, Jerome WG, Small DM, Warner GJ, Stoltenborg JK, Kearney MA, Corjay MH, Phillips MC, Rothblat $\mathrm{GH}$. Effects of intracellular free cholesterol accumulation on macrophage viability: a model for foam cell death. Arterioscler Thromb Vasc Biol. 1998;18:423-431.

8. Goo Y-H, Yechoor VK, Paul A. Transcriptional profiling of foam cells in response to hypercholesterolemia. Genomics data. 2016;9:37-9.

9. Brown AJ, Mander EL, Gelissen IC, Kritharides L, Dean RT, Jessup W. Cholesterol and oxysterol metabolism and subcellular distribution in macrophage foam cells. Accumulation of oxidized

10. Tangirala RK, Jerome WG, Jones NL, Small DM, Johnson WJ, Glick JM, Mahlberg FH, Rothblat GH. Formation of cholesterol monohydrate crystals in macrophage-derived foam cells. J Lipid Res. 1994;35:93-104.

11. Feng B, Yao PM, Li Y, Devlin CM, Zhang D, Harding HP, Sweeney M, Rong JX, Kuriakose G, Fisher EA, Marks AR, Ron $D$, Tabas I. The endoplasmic reticulum is the site of cholesterolinduced cytotoxicity in macrophages. Nat Cell Biol. 2003;5:781792.

12. van Tits LJH, Stienstra R, van Lent PL, Netea MG, Joosten LAB, Stalenhoef AFH. Oxidized LDL enhances pro-inflammatory responses of alternatively activated M2 macrophages: a crucial role for Krüppel-like factor 2. Atherosclerosis. 2011;214:345349.

13. Stewart CR, Stuart LM, Wilkinson K, van Gils JM, Deng J, Halle A, Rayner KJ, Boyer L, Zhong R, Frazier WA, Lacy-Hulbert A, El Khoury J, Golenbock DT, Moore KJ. CD36 ligands promote sterile inflammation through assembly of a Toll-like receptor 4 and 6 heterodimer. Nat Immunol. 2010;11:155-161.

14. Chávez-Sánchez L, Garza-Reyes MG, Espinosa-Luna JE, Chávez-Rueda K, Legorreta-Haquet MV, Blanco-Favela F. The role of TLR2, TLR4 and CD36 in macrophage activation and foam cell formation in response to oxLDL in humans. Hum Immunol. 2014;75:322-9.

15. Tabas I. Consequences and therapeutic implications of macrophage apoptosis in atherosclerosis: the importance of lesion stage and phagocytic efficiency. Arterioscler Thromb Vasc Biol. 2005;25:2255-2264.

16. Schrijvers DM, De Meyer GRY, Kockx MM, Herman AG, Martinet W. Phagocytosis of apoptotic cells by macrophages is impaired in atherosclerosis. Arterioscler Thromb Vasc Biol. 2005;25:125661.

17. Tabas I. Apoptosis and plaque destabilization in atherosclerosis: the role of macrophage apoptosis induced by cholesterol. Cell Death Differ. 2004;11 Suppl 1:S12-16. 
bioRxiv preprint doi: https://doi.org/10.1101/715565; this version posted July 26, 2019. The copyright holder for this preprint (which was not certified by peer review) is the author/funder, who has granted bioRxiv a license to display the preprint in perpetuity. It is made available under aCC-BY-ND 4.0 International license.

18. McNeill E, lqbal AJ, Jones D, Patel J, Coutinho P, Taylor L, Greaves DR, Channon KM. Tracking Monocyte Recruitment and Macrophage Accumulation in Atherosclerotic Plaque Progression Using a Novel hCD68GFP/ApoE-/- Reporter MouseBrief Report. Arterioscler Thromb Vasc Biol. 2017;37:258-263.

19. Badrnya S, Schrottmaier WC, Kral JB, Yaiw K-C, Volf I, Schabbauer G, Söderberg-Nauclér C, Assinger A. Platelets mediate oxidized low-density lipoprotein-induced monocyte extravasation and foam cell formation. Arterioscler Thromb Vasc Biol. 2014;34:571-80.

20. Lopes-Virella MF, Virella G. Pathogenic role of modified LDL antibodies and immune complexes in atherosclerosis. $J$ Atheroscler Thromb. 2013;20:743-54.

21. Lichtman AH, Clinton SK, liyama K, Connelly PW, Libby P, Cybulsky Ml. Hyperlipidemia and atherosclerotic lesion development in LDL receptor-deficient mice fed defined semipurified diets with and without cholate. Arterioscler Thromb Vasc Biol. 1999;19:1938-44.

22.

Ensan S, Li A, Besla R, Degousee N, Cosme J, Roufaiel M, Shikatani EA, El-Maklizi M, Williams JW, Robins L, Li C, Lewis B, Yun TJ, Lee JS, Wieghofer P, Khattar R, Farrokhi K, Byrne J, Ouzounian M, Zavitz CCJ, Levy GA, Bauer CMT, Libby P, Husain M, Swirski FK, Cheong C, Prinz M, Hilgendorf I, Randolph GJ, Epelman S, Gramolini AO, Cybulsky MI, Rubin BB, Robbins CS. Self-renewing resident arterial macrophages arise from embryonic CX3CR1(+) precursors and circulating monocytes immediately after birth. Nat Immunol. 2016;17:159-68.

23. Lavine KJ, Epelman S, Uchida K, Weber KJ, Nichols CG, Schilling JD, Ornitz DM, Randolph GJ, Mann DL. Distinct macrophage lineages contribute to disparate patterns of cardiac recovery and remodeling in the neonatal and adult heart. Proc Natl Acad Sci U S A. 2014;111:16029-34.

24. Hoeksema MA, Glass CK. Nature and nurture of tissue-specific macrophage phenotypes. Atherosclerosis. 2019;281:159-167.

25. Mahbub S, Deburghgraeve CR, Kovacs EJ. Advanced age impairs macrophage polarization. J Interferon Cytokine Res. 2012;32:18-26.

26. Davis MJ, Tsang TM, Qiu Y, Dayrit JK, Freij JB, Huffnagle GB, Olszewski MA. Macrophage M1/M2 polarization dynamically adapts to changes in cytokine microenvironments in Cryptococcus neoformans infection. MBio. 2013;4:e00264-13.

27. Cochain C, Vafadarnejad E, Arampatzi P, Pelisek J, Winkels $\mathrm{H}$, Ley K, Wolf D, Saliba A-E, Zernecke A. Single-Cell RNA-Seq Reveals the Transcriptional Landscape and Heterogeneity of Aortic Macrophages in Murine Atherosclerosis. Circ Res. 2018;122:1661-1674.

28.

Stöger JL, Gijbels MJJ, van der Velden S, Manca M, van der Loos CM, Biessen EAL, Daemen MJAP, Lutgens E, de Winther MPJ. Distribution of macrophage polarization markers in human atherosclerosis. Atherosclerosis. 2012;225:461-8.

29. Boyle JJ, Harrington HA, Piper E, Elderfield K, Stark J, Landis RC, Haskard DO. Coronary intraplaque hemorrhage evokes a novel atheroprotective macrophage phenotype. Am J Pathol. 2009;174:1097-108.

30. Boyle JJ, Johns M, Kampfer T, Nguyen AT, Game L, Schaer DJ, Mason JC, Haskard DO. Activating transcription factor 1 directs Mhem atheroprotective macrophages through coordinated iron handling and foam cell protection. Circ Res. 2012;110:20-33.

31. Kadl A, Meher AK, Sharma PR, Lee MY, Doran AC, Johnstone SR, Elliott MR, Gruber F, Han J, Chen W, Kensler T, Ravichandran KS, Isakson BE, Wamhoff BR, Leitinger N. Identification of a novel macrophage phenotype that develops in response to atherogenic phospholipids via Nrf2. Circ Res. 2010;107:737-46

32. Sussan TE, Jun J, Thimmulappa R, Bedja D, Antero M, Gabrielson KL, Polotsky VY, Biswal S. Disruption of Nrf2, a key inducer of antioxidant defenses, attenuates ApoE-mediated atherosclerosis in mice. PLoS One. 2008;3:e3791.

33. Stary HC, Chandler AB, Dinsmore RE, Fuster V, Glagov S, Insull W, Rosenfeld ME, Schwartz CJ, Wagner WD, Wissler RW. A definition of advanced types of atherosclerotic lesions and a histological classification of atherosclerosis. A report from the Committee on Vascular Lesions of the Council on Arteriosclerosis, American Heart Association. Circulation. 1995;92:1355-74.

34. Swirski FK, Libby P, Aikawa E, Alcaide P, Luscinskas FW, Weissleder R, Pittet MJ. Ly-6Chi monocytes dominate hypercholesterolemia-associated monocytosis and give rise to macrophages in atheromata. J Clin Invest. 2007;117:195-205.

35. Tang J, Lobatto ME, Hassing L, van der Staay S, van Rijs SM Calcagno C, Braza MS, Baxter S, Fay F, Sanchez-Gaytan BL, Duivenvoorden $R$, Sager $H$, Astudillo YM, Leong $W$, Ramachandran S, Storm G, Pérez-Medina C, Reiner T, Cormode DP, Strijkers GJ, Stroes ESG, Swirski FK, Nahrendorf M, Fisher EA, Fayad ZA, Mulder WJM. Inhibiting macrophage proliferation suppresses atherosclerotic plaque inflammation. Sci Adv. 2015;1.

36. Koller D, Hackl H, Bogner-Strauß JG, Hermetter A. Effects of oxidized phospholipids on gene expression in RAW 264.7 macrophages: a microarray study. PLoS One. 2014;9:e110486.

37. Ho M-M, Fraser DA. Transcriptome data and gene ontology analysis in human macrophages ingesting modified lipoproteins in the presence or absence of complement protein C1q. Data Br 2016;9:362-367.

38. Albarrán-Juárez $J$, Kaur $H$, Grimm $M$, Offermanns $S$ Wettschureck $\mathrm{N}$. Lineage tracing of cells involved in atherosclerosis. Atherosclerosis. 2016;251:445-453.

39. Muiya NP, Wakil S, Al-Najai M, Tahir Al, Baz B, Andres E, AlBoudari O, Al-Tassan N, Al-Shahid M, Meyer BF, Dzimiri N. A study of the role of GATA2 gene polymorphism in coronary artery disease risk traits. Gene. 2014;544:152-8.

40. Nandakumar SK, Johnson K, Throm SL, Pestina TI, Neale G, Persons DA. Low-level GATA2 overexpression promotes myeloid progenitor self-renewal and blocks lymphoid differentiation in mice. Exp Hematol. 2015;43:565-77.e1-10.

41. Collin M, Dickinson R, Bigley V. Haematopoietic and immune defects associated with GATA2 mutation. $\mathrm{Br} J$ Haematol. 2015;169:173-87.

42. Heit B, Kim H, Cosío G, Castaño D, Collins R, Lowell CA, Kain KC, Trimble WS, Grinstein S. Multimolecular signaling complexes enable Syk-mediated signaling of CD36 internalization. Dev Cell. 2013;24:372-83.

43. Luo J, Jiang L, Yang H, Song B-L. Routes and mechanisms of post-endosomal cholesterol trafficking: A story that never ends. Traffic. 2017;18:209-217.

44. Nagao T, Qin C, Grosheva I, Maxfield FR, Pierini LM. Elevated cholesterol levels in the plasma membranes of macrophages inhibit migration by disrupting RhoA regulation. Arterioscler Thromb Vasc Biol. 2007;27:1596-1602.

45. Fuhrman B, Judith O, Keidar S, Ben-Yaish L, Kaplan M, Aviram $M$. Increased uptake of LDL by oxidized macrophages is the result of an initial enhanced LDL receptor activity and of a further progressive oxidation of LDL. Free Radic Biol Med. 1997;23:3446.

46. Cai B, Thorp EB, Doran AC, Sansbury BE, Daemen MJAP, Dorweiler B, Spite M, Fredman G, Tabas I. MerTK receptor cleavage promotes plaque necrosis and defective resolution in atherosclerosis. J Clin Invest. 2017;127:1-5.

47. Thorp E, Subramanian M, Tabas I. The role of macrophages and dendritic cells in the clearance of apoptotic cells in advanced atherosclerosis. Eur J Immunol. 2011;41:2515-8.

48. Blackburn JWD, Lau DHC, Liu EY, Ellins J, Vrieze AM, Pawlak EN, Dikeakos JD, Heit B. Soluble CD93 is an apoptotic cell 
bioRxiv preprint doi: https://doi.org/10.1101/715565; this version posted July 26, 2019. The copyright holder for this preprint (which was not certified by peer review) is the author/funder, who has granted bioRxiv a license to display the preprint in perpetuity. It is made available under aCC-BY-ND 4.0 International license.

opsonin recognized by ax $\beta 2$. Eur J Immunol. 2019;49:600-610.

49. Poteryaev D, Datta S, Ackema K, Zerial M, Spang A. Identification of the switch in early-to-late endosome transition. Cell. 2010;141:497-508.

50. Downey GP, Botelho RJ, Butler JR, Moltyaner Y, Chien P, Schreiber AD, Grinstein S. Phagosomal maturation, acidification, and inhibition of bacterial growth in nonphagocytic cells transfected with FcgammaRIIA receptors. J Biol Chem. 1999;274:28436-44.

51. Nunes P, Demaurex N, Dinauer MC. Regulation of the NADPH oxidase and associated ion fluxes during phagocytosis. Traffic. 2013;14:1118-31.

52. Yin C, Kim Y, Argintaru D, Heit B. Rab17 mediates differential antigen sorting following efferocytosis and phagocytosis. Cell Death Dis. 2016;7:e2529.

53. Geraldino-Pardilla L, Giles JT, Sokolove J, Zartoshti A, Robinson WH, Budoff M, Detrano R, Bokhari S, Bathon JM. Association of Anti-Citrullinated Peptide Antibodies With Coronary Artery Calcification in Rheumatoid Arthritis. Arthritis Care Res (Hoboken). 2017;69:1276-1281.

54. Cambridge G, Acharya J, Cooper JA, Edwards JC, Humphries SE. Antibodies to citrullinated peptides and risk of coronary heart disease. Atherosclerosis. 2013;228:243-6.

55. Sokolove J, Brennan MJ, Sharpe O, Lahey LJ, Kao AH, Krishnan E, Edmundowicz D, Lepus CM, Wasko MC, Robinson WH. Citrullination within the atherosclerotic plaque: A potential target for the anti-citrullinated protein antibody response in rheumatoid arthritis. Arthritis Rheum. 2013;65:1719-1724.

56. A-Gonzalez N, Quintana JA, García-Silva S, Mazariegos M, González de la Aleja A, Nicolás-Ávila JA, Walter W, Adrover JM, Crainiciuc G, Kuchroo VK, Rothlin C V, Peinado H, Castrillo A, Ricote M, Hidalgo A. Phagocytosis imprints heterogeneity in tissue-resident macrophages. J Exp Med. 2017;214:1281-1296.

57. Thorp EB. Mechanisms of failed apoptotic cell clearance by phagocyte subsets in cardiovascular disease. Apoptosis. 2010;15:1124-36.

58. Thorp E, Tabas I. Mechanisms and consequences of efferocytosis in advanced atherosclerosis. J Leukoc Biol. 2009;86:1089-95.

59. Linton MF, Babaev VR, Huang J, Linton EF, Tao H, Yancey PG. Macrophage Apoptosis and Efferocytosis in the Pathogenesis of Atherosclerosis. Circ J. 2016;80:2259-2268.

60. Beyer M, Mallmann MR, Xue J, Staratschek-Jox A, Vorholt D, Krebs W, Sommer D, Sander J, Mertens C, Nino-Castro A Schmidt S V., Schultze JL. High-resolution transcriptome of human macrophages. PLoS One. 2012;7:e45466.

61. Robbins CS, Hilgendorf I, Weber GF, Theurl I, Iwamoto Y, Figueiredo J-L, Gorbatov R, Sukhova GK, Gerhardt LMS, Smyth D, Zavitz CCJ, Shikatani EA, Parsons M, van Rooijen N, Lin HY, Husain M, Libby P, Nahrendorf M, Weissleder R, Swirski FK. Local proliferation dominates lesional macrophage accumulation in atherosclerosis. Nat Med. 2013;19:1166-72.

62. Zhang $P$, Behre $G$, Pan J, Iwama A, Wara-Aswapati $N$, Radomska HS, Auron PE, Tenen DG, Sun Z. Negative cross-talk between hematopoietic regulators: GATA proteins repress PU.1. Proc Natl Acad Sci U S A. 1999;96:8705-10.

63. Theilgaard-Mönch $\mathrm{K}$, Jacobsen LC, Borup R, Rasmussen $T$, Bjerregaard MD, Nielsen FC, Cowland JB, Borregaard N. The transcriptional program of terminal granulocytic differentiation. Blood. 2005;105:1785-96.

64. Kanki $\mathrm{Y}$, Kohro T, Jiang S, Tsutsumi S, Mimura I, Suehiro J-I, Wada $\mathrm{Y}$, Ohta $\mathrm{Y}$, Ihara S, Iwanari $\mathrm{H}$, Naito M, Hamakubo $\mathrm{T}$, Aburatani H, Kodama T, Minami T. Epigenetically coordinated GATA2 binding is necessary for endothelium-specific endomucin expression. EMBO J. 2011;30:2582-95.
65. Marks-Bluth J, Khanna A, Chandrakanthan V, Thoms J, Bee T, Eich C, Kang YC, Knezevic K, Qiao Q, Fitch S, Oxburgh L, Ottersbach K, Dzierzak E, de Bruijn MFTR, Pimanda JE. SMAD1 and SMAD5 Expression Is Coordinately Regulated by FLI1 and GATA2 during Endothelial Development. Mol Cell Biol. 2015;35:2165-72.

66. Kazenwadel J, Betterman KL, Chong C-E, Stokes PH, Lee YK, Secker GA, Agalarov Y, Demir CS, Lawrence DM, Sutton DL, Tabruyn SP, Miura N, Salminen M, Petrova T V, Matthews JM, Hahn CN, Scott HS, Harvey NL. GATA2 is required for lymphatic vessel valve development and maintenance. J Clin Invest. 2015;125:2979-94.

67. Johnson KD, Hsu AP, Ryu M-J, Wang J, Gao X, Boyer ME, Liu Y, Lee Y, Calvo KR, Keles S, Zhang J, Holland SM, Bresnick EH. Cis-element mutated in GATA2-dependent immunodeficiency governs hematopoiesis and vascular integrity. J Clin Invest. 2012;122:3692-704.

68. Hsu AP, Sampaio EP, Khan J, Calvo KR, Lemieux JE, Patel SY, Frucht DM, Vinh DC, Auth RD, Freeman AF, Olivier KN, Uzel G, Zerbe CS, Spalding C, Pittaluga S, Raffeld M, Kuhns DB, Ding L, Paulson ML, Marciano BE, Gea-Banacloche JC, Orange JS, Cuellar-Rodriguez J, Hickstein DD, Holland SM. Mutations in GATA2 are associated with the autosomal dominant and sporadic monocytopenia and mycobacterial infection (MonoMAC) syndrome. Blood. 2011;118:2653-5.

69. Lasbury ME, Tang X, Durant PJ, Lee C-H. Effect of transcription factor GATA-2 on phagocytic activity of alveolar macrophages from Pneumocystis carinii-infected hosts. Infect Immun 2003;71:4943-52.

70. Paul F, Arkin Y, Giladi A, Jaitin DA, Kenigsberg E, Keren-Shaul H, Winter D, Lara-Astiaso D, Gury M, Weiner A, David E, Cohen N, Lauridsen FKB, Haas S, Schlitzer A, Mildner A, Ginhoux F, Jung S, Trumpp A, Porse BT, Tanay A, Amit I. Transcriptional Heterogeneity and Lineage Commitment in Myeloid Progenitors. Cell. 2015;163:1663-77.

71. Lim HY, Lim SY, Tan CK, Thiam CH, Goh CC, Carbajo D, Chew SHS, See P, Chakarov S, Wang XN, Lim LH, Johnson LA, Lum J, Fong CY, Bongso A, Biswas A, Goh C, Evrard M, Yeo KP, Basu R, Wang JK, Tan Y, Jain R, Tikoo S, Choong C, Weninger W, Poidinger M, Stanley RE, Collin M, Tan NS, Ng LG, Jackson DG, Ginhoux F, Angeli V. Hyaluronan Receptor LYVE-1Expressing Macrophages Maintain Arterial Tone through Hyaluronan-Mediated Regulation of Smooth Muscle Cell Collagen. Immunity. 2018;49:326-341.e7.

72. Moore KJ, Sheedy FJ, Fisher E a. Macrophages in atherosclerosis: a dynamic balance. Nat Rev Immunol. 2013;13:709-21.

73. Wolf $\mathrm{D}$, Zirlik A, Ley K. Beyond vascular inflammation--recent advances in understanding atherosclerosis. Cell Mol Life Sci. 2015;72:3853-69.

74. Martinez FO, Gordon S, Locati M, Mantovani A. Transcriptional Profiling of the Human Monocyte-to-Macrophage Differentiation and Polarization: New Molecules and Patterns of Gene Expression. J Immunol. 2006;177:7303-7311.

75. Tong Q, Dalgin G, Xu H, Ting CN, Leiden JM, Hotamisligil GS. Function of GATA transcription factors in preadipocyte-adipocyte transition. Science. 2000;290:134-8.

76. Schindelin J, Arganda-Carreras I, Frise E, Kaynig V, Longair M, Pietzsch T, Preibisch S, Rueden C, Saalfeld S, Schmid B, Tinevez J-Y, White DJ, Hartenstein V, Eliceiri K, Tomancak P, Cardona A. Fiji: an open-source platform for biological-image analysis. Nat Methods. 2012;9:676-82.

77. Evans AL, Blackburn JWD, Yin C, Heit B. Quantitative Efferocytosis Assays. Methods Mol Biol. 2017;1519:25-41.

78. Gentleman RC, Carey VJ, Bates DM, Bolstad B, Dettling M, Dudoit S, Ellis B, Gautier L, Ge Y, Gentry J, Hornik K, Hothorn T, Huber W, lacus S, Irizarry R, Leisch F, Li C, Maechler M, Rossini AJ, Sawitzki G, Smith C, Smyth G, Tierney L, Yang JYH, Zhang 
bioRxiv preprint doi: https://doi.org/10.1101/715565; this version posted July 26, 2019. The copyright holder for this preprint (which was not certified by peer review) is the author/funder, who has granted bioRxiv a license to display the preprint in perpetuity. It is made available under aCC-BY-ND 4.0 International license.

J. Bioconductor: open software development for computational biology and bioinformatics. Genome Biol. 2004;5:R80.

79. Lara-Guzmán OJ, Gil-Izquierdo Á, Medina S, Osorio E, ÁlvarezQuintero R, Zuluaga N, Oger C, Galano J-M, Durand T, MuñozDurango K. Oxidized LDL triggers changes in oxidative stress and inflammatory biomarkers in human macrophages. Redox Biol. 2018;15:1-11.

80. Pawlak EN, Dirk BS, Jacob RA, Johnson AL, Dikeakos JD. The HIV-1 accessory proteins Nef and Vpu downregulate total and cell surface CD28 in CD4+ T cells. Retrovirology. 2018;15:6.

81. Taruc K, Yin C, Wootton DG, Heit B. Quantification of
Efferocytosis by Single-cell Fluorescence Microscopy. J Vis Exp. 2018;

82. Trinh LA, McCutchen MD, Bonner-Fraser M, Fraser SE, Bumm LA, McCauley DW. Fluorescent in situ hybridization employing the conventional NBT/BCIP chromogenic stain. Biotechniques. 2007;42:756-9.

83. Sankaranarayanan S, Kellner-Weibel G, de la Llera-Moya M, Phillips MC, Asztalos BF, Bittman R, Rothblat GH. A sensitive assay for ABCA1-mediated cholesterol efflux using BODIPYcholesterol. J Lipid Res. 2011;52:2332-2340. 